\title{
Reelin Deficiency and Displacement of Mature Neurons, But Not Neurogenesis, Underlie the Formation of Granule Cell Dispersion in the Epileptic Hippocampus
}

\author{
Christophe Heinrich, ${ }^{1,3,4}$ Naoki Nitta, ${ }^{5}$ Armin Flubacher, ${ }^{1,3}$ Martin Müller, ${ }^{1,2}$ Alexander Fahrner, ${ }^{1,3}$ Matthias Kirsch, ${ }^{3}$ \\ Thomas Freiman, ${ }^{2}$ Fumio Suzuki, ${ }^{5}$ Antoine Depaulis, ${ }^{4}$ Michael Frotscher, ${ }^{3 *}$ and Carola A. Haas ${ }^{1,3 *}$ \\ ${ }^{1}$ Experimental Epilepsy Group and ${ }^{2}$ Department of Neurosurgery, Neurocenter, and ${ }^{3}$ Institute of Anatomy and Cell Biology, University of Freiburg, D-79106 \\ Freiburg, Germany, ${ }^{4}$ Institut National de la Santé et de la Recherche Médicale U704, F-38400 Grenoble, France, and ${ }^{5}$ Department of Neurosurgery, Shiga \\ University, Ohtsu, Shiga 520-2192, Japan
}

\begin{abstract}
Mesio-temporal lobe epilepsy (MTLE) is often accompanied by granule cell dispersion (GCD), a widening of the granule cell layer. The molecular determinants of GCD are poorly understood. Here, we used an animal model to study whether GCD results from an increased dentate neurogenesis associated with an abnormal migration of the newly generated granule cells. Adult mice were given intrahippocampal injections of kainate (KA) known to induce focal epileptic seizures and GCD, comparable to the changes observed in human MTLE. Ipsilateral GCD progressively developed after KA injection and was paralleled by a gradual decrease in the expression of doublecortin, a marker of newly generated granule cells, in the dentate subgranular layer. Staining with Fluoro-Jade B revealed little cell degeneration in the subgranular layer on the KA-injected side. Labeling with bromodeoxyuridine showed an early, transient increase in mitotic activity in the dentate gyrus of the KA-injected hippocampus that gave rise to microglial cells and astrocytes but not to new neurons. Moreover, at later time points, there was a virtually complete cessation of mitotic activity in the injected hippocampus (where GCD continued to develop), but not on the contralateral side (where no GCD was observed). Finally, a significant decrease in reelin mRNA synthesis in the injected hippocampus paralleled the development of GCD, and neutralization of reelin by application of the CR-50 antibody induced GCD. These results show that GCD does not result from increased neurogenesis but reflects a displacement of mature granule cells, most likely caused by a local reelin deficiency.
\end{abstract}

Key words: dentate gyrus; mesio-temporal lobe epilepsy; Ammon's horn sclerosis; reelin; neuronal migration; Cajal-Retzius cell

\section{Introduction}

During brain development, neurons migrate long distances from the ventricular zone to their proper positions in the cortical plate. Altered migration results in a malpositioning of cortical neurons with functional consequences such as mental retardation and epilepsy (Palmini et al., 1991; Eksioglu et al., 1996; des Portes et al., 1998; Hong et al., 2000). In mesio-temporal lobe epilepsy (MTLE), a common form of focal epilepsies (Margerison and Corsellis, 1966; Cendes et al., 2002), a malpositioning of dentate granule cells, termed granule cell dispersion (GCD), has been reported (Houser, 1990). It is an open question whether GCD is a developmental defect or the result of epileptic seizure activity.

\footnotetext{
Received April 14, 2005; revised Feb. 13, 2006; accepted March 14, 2006.

This work was supported by the Deutsche Forschungsgemeinschaft (Transregio SFB TR3), the German Federal Ministry of Education and Research (Grant 01GQ0420), Institut National de la Santé et de la Recherche Médicale, and Neurex. We are grateful to $S$. Huber and H. Banse for excellent technical assistance. We thank Dr. J. C. Deloulme for generously providing the RC2 and GLAST antibodies, Drs. J. Herz and I. Schüttmann for reagents and suggestions, and Drs. K. Nakajima and T. Mikoshiba for the gift of the CR-50 antibody. We are grateful to Dr. L. Pain for support with the statistical analysis and to Dr. Y. Larmet for help with the TUNEL staining.

${ }^{*} M . F$. and C.A.H. contributed equally to this work.

Correspondence should be addressed to Dr. Carola A. Haas, Experimental Epilepsy Group, Neurocenter, University Clinic Freiburg, Breisacher Strasse 64, D-79106 Freiburg, Germany. E-mail: Carola.Haas@uniklinik-freiburg.de. DOI:10.1523/JNEUROSCI.5516-05.2006

Copyright $\odot 2006$ Society for Neuroscience $\quad$ 0270-6474/06/264701-13\$15.00/0
}

GCD is mainly observed in MTLE patients who experienced febrile convulsive seizures in early infancy, suggesting an initial precipitating event as a trigger for the development of GCD (Houser et al., 1990; Lurton et al., 1998). However, a unique feature of dentate granule cells is their enduring postnatal generation (Altman and Das, 1965; Kaplan and Hinds, 1977; Eriksson et al., 1998), which in rodents is stimulated by prolonged epileptic activity (Parent et al., 1997; Scharfman et al., 2000). Thus, GCD may alternatively develop in the adult stage resulting from an increased neurogenesis after recurrent epileptic seizures and an aberrant migration of these newly generated granule cells.

The extracellular matrix protein reelin controls neuronal migration (Frotscher, 1998; Tissir and Goffinet, 2003). The reeler mouse deficient in Reelin (Rakic and Caviness, 1995; D’Arcangelo et al., 1995; Hirotsune et al., 1995), mouse mutants deficient in apolipoprotein E receptor 2 and the very-low-density lipoprotein receptor, as well as mice deficient in the adaptor protein Disabled 1 (Dab1) (Howell et al., 1997; Sheldon et al., 1997; D’Arcangelo et al., 1999; Trommsdorf et al., 1999) all show granule cell migration defects. This indicates that the reelin signaling pathway plays a crucial role in the correct positioning of dentate granule cells. Therefore, we hypothesized that GCD observed in MTLE patients could result from alterations in reelin expression. 
We have indeed recently shown that a local, decreased expression of reelin mRNA correlates with the extent of GCD in the dentate gyrus of MTLE patients (Haas et al., 2002). Loss of reelin, in turn, may result from excitotoxic damage of reelin-synthesizing CajalRetzius cells known to be highly sensitive to glutamate and glutamate agonists, respectively (Del Rio et al., 1997).

To better understand the development of GCD, we used intrahippocampal kainate injection in the mouse, the only animal epilepsy model in which the development of GCD can be induced (Suzuki et al., 1995; Bouilleret et al., 1999; Riban et al., 2002). We monitored the time course of GCD development and studied whether or not increased neurogenesis and changes in reelin expression are involved in GCD formation. Our data provide evidence that GCD does not result from seizure-induced neurogenesis but from a displacement of mature granule cells, likely caused by a local reelin deficiency.

\section{Materials and Methods}

Animals. Experiments were conducted on adult C57BL/6 male mice [8-10 weeks of age; Janvier (Le-Genest-St-Isle, France) and CLEA (Tokyo, Japan)]. After surgery (see below), mice were housed in individual cages with food and water ad libitum and kept in a $12 \mathrm{~h}$ light/dark cycle (room temperature, $22 \pm 1^{\circ} \mathrm{C}$ ). All animal procedures were performed in accordance with the guidelines of the European Community Council Directive of November 24, 1986 (86/609/EEC). All efforts were made to minimize animal suffering and to reduce the number of animals used.

Surgery. Mice were anesthetized with chloral hydrate ( $400 \mathrm{mg} / \mathrm{kg}$, i.p.) and placed in a stereotaxic frame in a flat skull position. A stainless steel cannula (outer diameter, $0.28 \mathrm{~mm}$ ) connected to a $0.5 \mu \mathrm{l}$ microsyringe (Hamilton, Bonaduz, Switzerland) via PE-20 tubing containing distilled water $\left(\mathrm{dH}_{2} \mathrm{O}\right)$ was filled with a $20 \mathrm{~mm}$ kainic acid (KA) solution (Sigma, Lyon, France) in $0.9 \%$ sterile $\mathrm{NaCl}$ and positioned in the right dorsal hippocampus [anteroposterior (AP), -1.9; mediolateral (ML), -1.5; dorsoventral (DV), $-2 \mathrm{~mm}$; with bregma as reference]. Mice were given injections for $1 \mathrm{~min}$ of $50 \mathrm{nl}(1 \mathrm{nmol})$ of the KA solution using a micropump (CMA/100; Carnegie Medicine, Stockholm, Sweden) operating the microsyringe. After injection, the cannula was left in the hippocampus for additional 2 min to avoid reflux along the cannula track. Control mice were given injections of $50 \mathrm{nl}$ of $0.9 \%$ sterile $\mathrm{NaCl}$ under the same conditions. After recovery from anesthesia, the animals were kept under observation for 8-10 h after KA injection. During this period, the animals experienced a status epilepticus characterized by mild clonic movements of the forelimbs, rotations, and immobility as described previously (Riban et al., 2002). This characteristic behavior has been shown to be associated with seizure activity consisting of bursts of spikes and discharges of spikes, poly-spikes and spike-and-waves recordable in both cortices and hippocampi, and lasted, at most, for $24 \mathrm{~h}$. After this period, the animals had recovered and no behavioral impairment was observed (C. Heinrich and A. Depaulis, unpublished observations). Only mice showing this characteristic behavioral pattern after KA injection were kept for further analysis.

Monitoring seizure activity. After intrahippocampal injection, mice were implanted with electrodes as described previously (Riban et al., 2002). Briefly, they were implanted in the ipsilateral hippocampus at the same coordinates as the injection site with a bipolar electrode, made of two twisted enamel-insulated stainless steel wires each soldered with a male connector (Wire Pro, Farnell, France). Mice were also equipped with three monopolar electrodes, made of a tungsten wire soldered with a male connector, that were placed over the left and the right frontoparietal cortices and the cerebellum (reference electrode). All electrodes were fixed on the skull with cyanoacrylate and dental acrylic cement.

Electroencephalographic (EEG) activity was recorded using a digital acquisition computer-based system (Coherence; sampling rate, $256 \mathrm{~Hz}$; Deltamed, Paris, France) in freely moving mice as described previously (Riban et al., 2002). Recording of hippocampal and cortical activities (for 2-3 h) was performed at 2 weeks after KA injection. Digitally recorded EEG activities were analyzed with the same software as for acquisition. A referential setup was used in which hippocampal and cortical electrodes were referenced with the electrode placed over the cerebellum.

Perfusion and tissue preparation. KA- and saline-injected mice were deeply anesthetized with an overdose of Nembutal (100 mg/kg, i.p.) at several postoperative survival times $(1 \mathrm{~d}, 2 \mathrm{~d}, 4 \mathrm{~d}, 7 \mathrm{~d}, 10 \mathrm{~d}, 14 \mathrm{~d}, 21 \mathrm{~d}, 5$ weeks, 6 weeks, and 4 months). They were perfused transcardially for 10 min with $4 \%$ paraformaldehyde in $0.1 \mathrm{~m}$ phosphate buffer, $\mathrm{pH}$ 7.4. The brains were removed from the skull and postfixed in the same fixative for $5 \mathrm{~h}$ at $4^{\circ} \mathrm{C}$. After fixation, the brains were either rinsed in $0.1 \mathrm{M} \mathrm{PBS}, \mathrm{pH}$ 7.4 (overnight at $4^{\circ} \mathrm{C}$ ), and cut in coronal sections of $50 \mu \mathrm{m}$ on a vibratome (VT100M; Leica, Nussloch, Germany) or subjected to cryoprotection $\left(20 \%\right.$ sucrose in PBS overnight at $\left.4^{\circ} \mathrm{C}\right)$, followed by cryostat sectioning (50 $\mu \mathrm{m}$, coronal plane). Sections were only chosen from the dorsal hippocampus, because GCD development is confined to this part of the hippocampus and does not extend to the temporal pole. They were collected in tissue culture dishes and either rinsed in PBS for immunocytochemistry or rinsed in $2 \times$ SSC for in situ hybridization $(1 \times$ SSC $=$ $0.15 \mathrm{M} \mathrm{NaCl}$ and $0.015 \mathrm{~m}$ sodium citrate, $\mathrm{pH} 7.0$ ).

In situ hybridization histochemistry. Reelin, synapsin I, brain-derived neurotrophic factor (BDNF), and doublecortin (DCX) mRNAs were localized by in situ hybridization with digoxigenin (DIG)-labeled cRNA probes generated by in vitro transcription from appropriate plasmids. Reelin, synapsin I, and BDNF cRNAs were prepared as described previously (Haas et al., 2000, 2002; Burbach et al., 2004). DCX cRNA was generated from an Image clone containing a $4.5 \mathrm{~kb}$ mouse DCX cDNA (GenBank accession number BC057010) ligated into a pYX-ASC vector.

For in situ hybridization, cryostat sections were pretreated in a 1:1 mixture of $2 \times$ SSC: hybridization buffer ( $50 \%$ formamide, $4 \times$ SSC, 50 $\mathrm{mm} \mathrm{NaH} \mathrm{PO}_{4}, 250 \mu \mathrm{g} / \mathrm{ml}$ heat-denatured salmon sperm DNA, 100 $\mu \mathrm{g} / \mathrm{ml}$ tRNA, $5 \%$ dextransulfate, and $1 \%$ Denhardt's solution) for $15 \mathrm{~min}$ and prehybridized in hybridization buffer for $60 \mathrm{~min}$ at $55^{\circ} \mathrm{C}\left(45^{\circ} \mathrm{C}\right.$ for reelin). Hybridization was performed in the same buffer including DIGlabeled antisense or sense cRNA probes, respectively (reelin and DCX, $100 \mathrm{ng} / \mathrm{ml}$; synapsin I, $70 \mathrm{ng} / \mathrm{ml}$; BDNF, $250 \mathrm{ng} / \mathrm{ml})$ at $55^{\circ} \mathrm{C}\left(45^{\circ} \mathrm{C}\right.$ for reelin) overnight. After hybridization, the brain sections were washed in $2 \times$ SSC (twice for $15 \mathrm{~min}$ ) at room temperature, in $2 \times$ SSC and $50 \%$ formamide, in $0.1 \times \mathrm{SSC}$ and $50 \%$ formamide for $15 \mathrm{~min}$ at $65^{\circ} \mathrm{C}\left(55^{\circ} \mathrm{C}\right.$ for reelin), and finally in $0.1 \times$ SSC (twice for $15 \mathrm{~min}$ ) at $65^{\circ} \mathrm{C}\left(55^{\circ} \mathrm{C}\right.$ for reelin). Immunological detection of DIG-labeled hybrids with an antiDIG antibody from sheep conjugated with alkaline phosphatase was performed as recommended by the manufacturer (Roche, Mannheim, Germany). Colorimetric detection was accomplished using nitroblue tetrazolium and 5-bromo-4-chloro-3-indolylphosphate. Development of the color reaction was performed in the dark and stopped by transfer into $10 \mathrm{~mm}$ Tris- $\mathrm{HCl}, \mathrm{pH} 8.0$, and $1 \mathrm{~mm}$ EDTA, when the desired intensity of the precipitate was reached. Tissue sections were mounted onto glass slides, air dried, and embedded in Moviol (Hoechst, Darmstadt, Germany).

Cell counts. Reelin mRNA-positive cells were counted in naive animals and in the ipsilateral and contralateral hippocampus of KA- and salineinjected mice. Cell counts were performed in the dorsal hippocampus along the hippocampal fissure in at least five consecutive sections close to the injection site at four postoperative survival times $(2 \mathrm{~d}, 7 \mathrm{~d}, 14 \mathrm{~d}$, and 6 weeks; $n=4$ each) at a magnification of $40 \times$ using a counting grid, defining an area of interest to a width of $500 \mu \mathrm{m}$ along the hippocampal fissure as described previously (Haas et al., 2002). Cell numbers were averaged for the ipsilateral and contralateral hippocampus of each animal and were expressed as a percentage of the contralateral side. For each group (time point), the numbers of reelin mRNA-expressing neurons were given as mean percentage \pm SEM.

DCX-immunostained cells were counted in the subgranular zone of the ipsilateral and contralateral dentate $2 \mathrm{~d}$ after KA injection $(n=3$; four sections per animal). Cell numbers were expressed as described above.

Immunocytochemistry. Either vibratome or cryostat sections were used for immunocytochemistry using a free-floating procedure. Free-floating sections were washed three times ( $15 \mathrm{~min}$ each) in $0.1 \mathrm{~m} \mathrm{PBS,} \mathrm{pH} \mathrm{7.2,}$ pretreated in $0.25 \%$ Triton X-100 in PBS for $30 \mathrm{~min}$, followed by incubation in $10 \%$ normal serum and $0.25 \%$ Triton X-100 in PBS for 20 min. Incubation with the primary antibody was performed for $5 \mathrm{~h}$ at room 
temperature, followed by an overnight incubation at $4^{\circ} \mathrm{C}$. The following primary antibodies were used: rabbit polyclonal anti-glial fibrillary acidic protein (GFAP; 1:500; Dako, Glostrup, Denmark), mouse monoclonal anti-NeuN (1:100; Chemicon, Temecula, CA), goat polyclonal anti-DCX (1:500, sc-8066; Santa Cruz Biotechnology, Santa Cruz, CA), goat polyclonal anti-vimentin (1:100, sc-7557; Santa Cruz Biotechnology), mouse anti-RC2 (1:10; Developmental Studies Hybridoma Bank, Iowa City, IA), guinea pig anti-astrocyte-specific glutamate transporter (GLAST; 1:4000, AB 1782; Chemicon), and rabbit anti-Iba-1 (1:3000; a kind gift from Dr. Y. Imai, National Institute of Neuroscience, Tokyo, Japan). After repeated washing in PBS, the sections were incubated with appropriate secondary antibodies conjugated with Cy3 or Cy2 (1:200; Jackson ImmunoResearch, West Grove, PA) or Alexa Fluor-488 (Invitrogen, Eugene, $\mathrm{OR}$ ) for $3 \mathrm{~h}$ in the dark at room temperature, followed by extensive washing in PBS for at least $1.5 \mathrm{~h}$. As a last step, tissue sections were mounted on gelatin-coated slides, air dried, and coverslipped with an anti-fading mounting medium (IMMU-Mount; ThermoShandon, Dreieich, Germany).

For double immunolabeling, tissue sections were pretreated as described above, except that normal serum was replaced by $1 \%$ bovine serum albumin. Incubation with the two primary antibodies was performed simultaneously as well as the exposure to the secondary antibodies. Washing steps and mounting of the sections were performed as described above.

Terminal deoxynucleotidyl transferase-mediated nick end labeling. DNA fragmentation was analyzed in vibratome sections cut at the level of the hippocampus 2 and $24 \mathrm{~h}$ after KA injection as described by Haas et al. (1996).

Bromodeoxyuridine labeling. Adult mice received intrahippocampal KA injection as described above. They then received intraperitoneal injections of bromodeoxyuridine (BrdU; $50 \mathrm{mg} / \mathrm{kg}$ body weight; Sigma) following two different protocols (see schematic diagram in supplemental Fig. 1, available at www.jneurosci.org as supplemental material). In the first group, mice received BrdU injections, four times per day (every $2 \mathrm{~h}$ ) at 6 and $7 \mathrm{~d}$ after KA injection (group 1), and were killed either $10 \mathrm{~d}$ or 5 weeks after KA injection. In the second group, mice were given, over 7 consecutive days, twice-daily BrdU injections, starting $8 \mathrm{~d}$ after KA administration, and were killed after the last BrdU injection corresponding to a $14 \mathrm{~d}$ survival time (group 2).

Animals were perfused transcardially, the brains were removed, and vibratome sections were collected as described. Tissue sections were washed twice in PBS, incubated in $2 \mathrm{~N} \mathrm{HCl}$ for $30 \mathrm{~min}$ at $37^{\circ} \mathrm{C}$, followed by neutralization in borate buffer $(0.1 \mathrm{M}, \mathrm{pH} 8.5)$ for $15 \mathrm{~min}$. Immunocytochemical detection of $\mathrm{BrdU}$ was accomplished by incubation with a rat monoclonal anti-BrdU antibody (1:500, \#OBT0030CX; Oxford Biotechnology, Oxford, UK) overnight at $4^{\circ} \mathrm{C}$, followed by the exposure to a secondary biotinylated anti-rat antibody (1:250; Vector Laboratories, Burlingame, CA). Visualization was performed by the avidin-biotin complex method (Elite ABC kit; Vector Laboratories) with diaminobenzidine as chromogen following standard procedures. Alternatively, BrdU was detected by immunofluorescence using an anti-rat IgG conjugated with Alexa Fluor-633 (1:200) for $2 \mathrm{~h}$ at room temperature. For identification of the BrdU-labeled cells, we performed triple labeling: tissue sections were pretreated with HistoMouse (Invitrogen, Karlsruhe, Germany), followed by simultaneous incubation with anti-BrdU (see above), mouse monoclonal anti-NeuN (1:100), and rabbit polyclonal anti-GFAP (1:500) at $4^{\circ} \mathrm{C}$ overnight, several washing steps, and exposure to fluorescently labeled secondary antibodies (all 1:200; Alexa Fluor-633 anti-rat IgG, Alexa Fluor-568 anti-mouse IgG, and Alexa Fluor-488 antirabbit $\mathrm{IgG}$ ) for $2 \mathrm{~h}$ at room temperature.

Fluoro-Jade B staining. To monitor KA-induced cell death, FluoroJade B staining was used, which is an established detection technique for degenerating neurons (Schmued and Hopkins, 2000). Vibratome sections, collected in $0.1 \mathrm{~m}$ PBS, were mounted on gelatin-coated slides and dried at room temperature overnight. Sections were rehydrated in $100 \%$ ethanol (EtOH; $5 \mathrm{~min}$ ), 70\% EtOH (2 min), and $\mathrm{dH}_{2} \mathrm{O}$ (2 min). After incubation in $0.06 \%$ potassium permanganate for $15 \mathrm{~min}$, sections were rinsed in $\mathrm{dH}_{2} \mathrm{O}(1 \mathrm{~min})$ and immersed for $30 \mathrm{~min}$ in $0.0004 \%$ FluoroJade B solution (Chemicon) in the dark. Thereafter, slides were washed in
$\mathrm{dH}_{2} \mathrm{O}$ (three times for $1 \mathrm{~min}$ ), air dried, cleared in xylene (three times for $2 \mathrm{~min}$ ), and coverslipped in Hypermount (ThermoShandon).

For the combination of Fluoro-Jade B staining and immunocytochemistry, sections were first immunostained and mounted on glass slides (as described above), followed by a modified Fluoro-Jade B staining procedure: after washing in $\mathrm{dH}_{2} \mathrm{O}$, the sections were transferred directly to the $0.06 \%$ potassium permanganate solution for $5 \mathrm{~min}$, stained with Fluoro-Jade B for $15 \mathrm{~min}$, air dried, and immediately observed using a fluorescence microscope omitting coverslipping.

Cresyl violet staining. To monitor the correct location of the injection site and the occurrence of cell death and GCD in the hippocampus after KA injection, a few tissue sections of each injected brain were analyzed by Nissl staining. Cryostat or vibratome sections were mounted on gelatincoated slides, immersed in a $0.1 \%$ cresyl violet solution for $10 \mathrm{~min}$, dehydrated in increasing concentrations of $\mathrm{EtOH}$, and coverslipped in Hypermount.

Microscopic analysis. All sections were examined with an Olympus (Tokyo, Japan) BX61 fluorescence microscope equipped with the appropriate filter sets and a digital camera. Digital images were acquired using the analySIS software (Soft Imaging System, Münster, Germany). Sections double-immunolabeled with NeuN and GFAP antibodies (see Fig. 6) and sections triple-immunolabeled with BrdU, NeuN, and GFAP antibodies (Fig. 4) were analyzed with a Axioplan2 fluorescence microscope equipped with an ApoTome setting (Carl Zeiss, Göttingen, Germany) and with a confocal microscope (LSM510 META; Carl Zeiss), respectively. Stacks of digital images were captured using the AxioVision software (Carl Zeiss). Single confocal images were then extracted from the stacks. Alternatively, the stacks were combined in one resulting picture using the extended focus function or reconstructed in a threedimensional illustration.

RNA extraction and reverse transcription. KA-injected mice were deeply anesthetized with $4 \%$ chloral hydrate and killed by decapitation at $2 \mathrm{~d}$ and 6 weeks after injection. The brains were removed rapidly from the skull, and the dorsal parts of the ipsilateral (injected) and the contralateral hippocampus were rapidly microdissected at $4^{\circ} \mathrm{C}$ and homogenized for RNA extraction. Total RNA was isolated using the RNeasy Mini kit (Qiagen, Hilden, Germany) according to the manufacturer's instructions. Reverse transcription (RT) was performed in $20 \mu \mathrm{l}$ reactions containing $\sim 1 \mu \mathrm{g}$ of total RNA, $5 \mu \mathrm{m}$ random decamer primers, $500 \mu \mathrm{M}$ deoxyNTPs, $20 \mathrm{U}$ of RNase inhibitor, and $100 \mathrm{U}$ of Moloney murine leukemia virus reverse transcriptase (all from Ambion, Huntingdon, $\mathrm{UK}$ ) for $60 \mathrm{~min}$ at $42^{\circ} \mathrm{C}$ following a standard protocol.

Real-time quantitative RT-PCR. An abundance of transcripts was determined by real-time quantitative PCR on a MyiQ Real-Time PCR Detection System (Bio-Rad Laboratories, München, Germany) with SYBR Green (ABgene, Hamburg, Germany). The following primers were used at 70 nM: murine reelin: forward 5'-CCCAGCCCAGACAGACAGTT-3', reverse 5'-CCAGGTGATGCCATTGTTGA-3'; murine DCX: forward $5^{\prime}$ ATTTCTCCTTGGATGAGAATGAA- $3^{\prime}$, reverse $5^{\prime}$-CCTGGGCTTTTAGCAGATGT-3'; murine BDNF: forward 5'-GGGTCACAGCGGCAGATAAA-3', reverse 5'-GCCTTTGGATACCGGGACTT-3'; murine S12: forward 5'-GGCATAGCTGCTGGAGGTGTAA-3', reverse 5'-GGGCTTGGCGCTTGTCTAA- $\left.3^{\prime}\right)$. Cycling conditions were as follows: $15 \mathrm{~min}$ at $95^{\circ} \mathrm{C}$, followed by 50 cycles of $15 \mathrm{~s}$ at $95^{\circ} \mathrm{C}$ and $1 \mathrm{~min}$ at $60^{\circ} \mathrm{C}$. Monitoring the fluorescence signal, which is proportional to the amount of double-stranded product, yielded complete amplification profiles. Melting curves of the amplified products were used to control for specificity of the amplification reaction. From the amplification curves obtained, a threshold cycle number $(\mathrm{Ct})$ was calculated, corresponding to the cycle number at which a user-defined fluorescence signal was reached. Differences in Ct values were used to calculate relative amounts of PCR product. Details of this relative quantification can be found at http://docs.appliedbiosystems.com/pebiodocs/ 04303859.pdf. All quantifications were normalized to an endogenous control (S12 RNA) to account for variability in the initial concentration. For each animal, the results were expressed as relative mRNA levels with the contralateral side defined as $100 \%$. For each group (at $2 \mathrm{~d}$ and 6 weeks after KA injection), the results were given as mean percentage \pm SEM. 
Statistical analysis. To assess the effect of KA injection on reelin-positive cell numbers, cell counting data (raw data) were subjected to a two-way, repeated-measure ANOVA (between-factor, time after KA injection; within-factor side, KA injected vs contralateral side). Differences in reelin cell numbers between the ipsilateral and contralateral side were then assessed for each time point after KA injection, by a post hoc analysis using a pairedsamples $t$ test. Our analysis included the following groups of mice: day 0 , naive untreated mice, day 2, day 7, day 14, and day 42 after KA injection). Differences were considered statistically significant when the probability value was $<0.05$.

Administration of the CR-50 monoclonal antibody to the adult mouse hippocampus. To neutralize endogenous reelin in the hippocampus of adult mice, the well characterized monoclonal CR-50 antibody with reelin-neutralizing activity (Ogawa et al., 1995; Nakajima et al., 1997) was chronically administered to the hippocampus of adult mice using a brain infusion kit (Alzet, Durect, Cupertino, CA). In brief, a brain infusion cannula was stereotaxically implanted into the right hippocampus (coordinates: AP, -1.9 ; ML, -1.5 ; DV, -1.5 ) and fixed to the scull with dental cement (also see above, Surgery). A catheter tubing (long enough to allow free head movement of the animal) was used to connect the cannula to the osmotic pump (volume, $100 \mu \mathrm{l}$ ), which was placed subcutaneously on the back of the animal. The pumps contained either CR-50 antibody solution (0.4 $\mu \mathrm{g} / \mu \mathrm{l}$ in DMEM; $n=6)$ or mouse IgG (0.4 $\mu \mathrm{g} / \mu \mathrm{l}$ in DMEM; Sigma, Taufkirchen, Germany) as a control $(n=5)$. The animals were infused for a period of $7 \mathrm{~d}$ and killed 1 week later. The brains were fixed by transcardial perfusion with $4 \%$ paraformaldehyde as described; consecutive sections of the entire hippocampus were cut on a vibratome and stained with cresyl violet for morphological analysis. For visualization of CR-50 diffusion in the injected hippocampus, some sections were incubated for $2 \mathrm{~h}$ with an anti-mouse $\mathrm{Cy} 3$ antibody, washed, and mounted on glass slides as described.

Quantitative analysis of granule cell layer width. Granule cell lamination was determined in cresyl violet-stained sections of CR-50-infused $(n=6)$ and mouse IgG-infused $(n=5)$ hippocampi. In five consecutive sections, five measurements each of granule cell layer width were performed at $25 \mu \mathrm{m}$ intervals in the region just underneath the infusion and in the same area of the granule cell layer on the contralateral side using the AxioVision software (Carl Zeiss). Statistical analysis included the mean and SEM and was based on 25 measurements on both the ipsilateral and contralateral sides.

\section{Results}

\section{Development of GCD after kainate injection into the dorsal hippocampus}

Single unilateral injections of kainate (KA) into the hippocampus of adult mice resulted in the degeneration of ipsilateral CA1, CA3, and hilar neurons (Fig. 1) (Suzuki et al., 1995; Bouilleret et al., 1999), which was observed as early as $2 \mathrm{~d}$ after KA injection (data not shown; $n=8$ ). Conversely, most CA2 pyramidal neurons and granule cells of the dentate gyrus appeared unaffected (Fig. 1). In addition, a progressive widening of the granule cell layer was noted in the injected hippocampus, resulting from both an in-
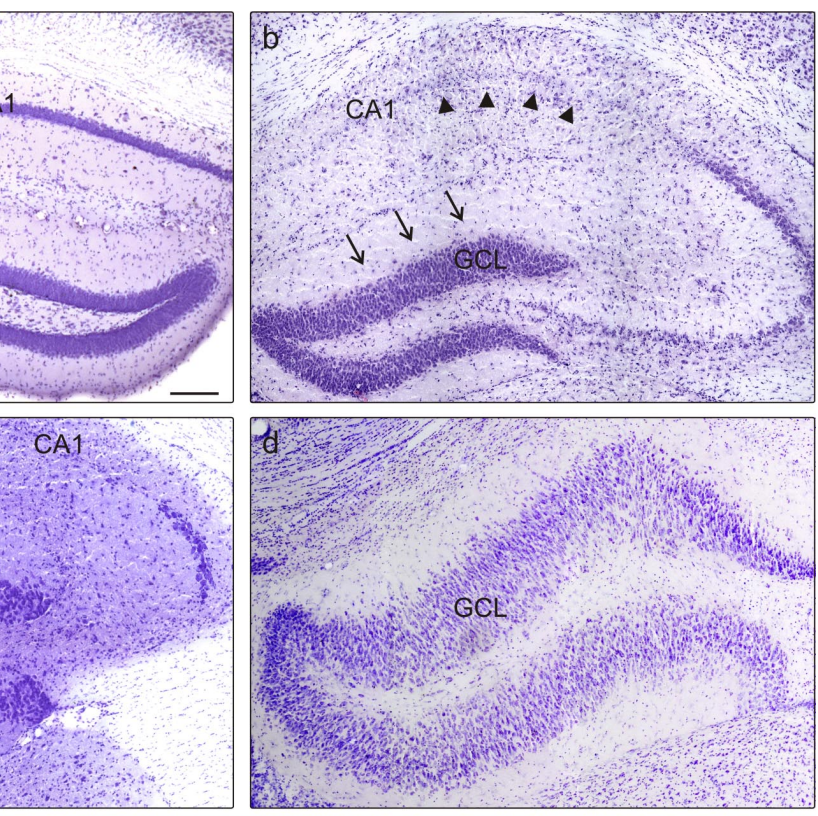

Figure 1. Development of GCD induced by unilateral intrahippocampal KA injection in the adult mouse. Coronal sections of the

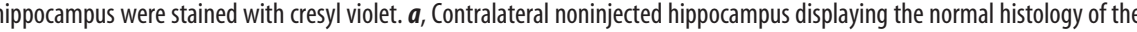
dispersion of the granule cells (arrows) is observed. Note the neuronal loss in CA1 (arrowheads), CA3, and the hilus. Scale bar, 100

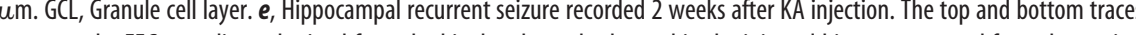
represent the EEG recordings obtained from the bipolar electrodes located in the injected hippocampus and from the cortical electrodes located over the left and the right frontoparietal cortex, respectively. Calibration: $1 \mathrm{~s}, 300 \mu \mathrm{V}$.

crease in granule cell size and GCD (Fig. 1) (Suzuki et al., 1995; Bouilleret et al., 1999). The described changes are predominantly found in the dorsal hippocampus in the vicinity of the injection site, leaving the ventral hippocampus unaffected.

In the ipsilateral hippocampus, a mild widening of the granule cell layer was already observed at $7 \mathrm{~d}(n=9)$ (Fig. $1 b)$ and was more pronounced at 3 weeks $(n=2)$ (Fig. $1 c)$. GCD reached an enormous extent 6 weeks after KA injection $(n=4)$ (Fig. $1 d)$. In contrast, no GCD was observed in the contralateral noninjected hippocampus (Fig. 1a) and in saline-injected controls $(n=6$; data not shown), in agreement with previous reports (Suzuki et al., 1995; Bouilleret et al., 1999).

In addition to these morphological changes, KA injection induced an initial nonconvulsive status epilepticus lasting for up to $15 \mathrm{~h}$ during which the animals showed mild clonic movements of the forelimbs, rotations, and/or immobilization. In some cases, bilateral clonic seizures of the forelimbs associated with rearing of the animals were observed, as described previously (Riban et al., 2002). In addition, recurrent spontaneous epileptic discharges with a frequency of 20-40 per hour and a duration of 10-30 s (Fig. 1e) occurred in the ipsilateral hippocampus 2 weeks after KA injection and could be recorded for the rest of the animals' life (Riban et al., 2002). Only data from animals with a characteristic 
status epilepticus and pattern of neuronal cell death were included in the present study.

\section{Loss of DCX expression in the dentate gyrus after kainate injection}

In the present study, we addressed the question whether increased dentate neurogenesis and malpositioning of the newly born granule cells contribute to the formation of GCD as hypothesized previously (Haas et al., 2002). We used DCX, which has been demonstrated to serve as a specific marker for newly generated neurons in the subgranular zone of the adult dentate gyrus and which is transiently expressed during migration and differentiation of these newly born granule cells (Brown et al., 2003; Rao and Shetty, 2004; Couillard-Dépres et al., 2005). Immunolabeling for DCX was performed on hippocampal sections of saline- and KA-injected mice 2 and $7 \mathrm{~d}$ and 4 and 6 weeks after injection.

A dense band of DCX-positive neurons was observed in the contralateral dentate gyrus such as in the dentate gyrus of salineinjected control animals (Fig. $2 a)(n=5)$. The majority of the DCX-positive somata was located either in the subgranular zone or in the inner one-third of the granule cell layer (Fig. 2c). Many DCX-positive neurons extended their dendritic arbors into the molecular layer (Fig. $2 a, c$ ), thus representing granule cells in the process of their differentiation. Two days after KA injection, this staining pattern had changed in the injected hippocampus: DCX-positive dendrites appeared shorter and strongly reduced in number, and the density of DCX-positive neuronal cell bodies was reduced compared with the contralateral side (Fig. 2b,d). Quantitative evaluation by cell counting revealed a slight reduction in DCX-positive cell numbers to $84.1 \pm 7.0 \%$ of contralateral levels. One week after KA injection, many gaps became apparent in the row of DCX-positive neurons in the subgranular zone $(n=7)$ (Fig. $2 e, g$, arrows), indicating a loss of DCX immunoreactivity in individual neurons. As a result, the remaining immunopositive neurons were arranged in small clusters instead of forming a continuous layer as observed at earlier time points or in controls (Fig. 2, compare $g$ with $c$ and $d$ ). Four and 6 weeks after KA injection, virtually all DCXimmunostained neurons had disappeared in the ipsilateral dentate gyrus $(n=3)$ (Fig. $2 f)$. In contrast, in the contralateral noninjected hippocampus and in saline-injected mice $(n=4)$, no reduction in DCX immunostaining could be detected at any of the time points investigated (Fig. 2a, $h$ ).

To complement this time course at the level of gene expression, we performed in situ hybridization for DCX mRNA at 3 weeks after KA injection $(n=2)$ (Fig. $2 i, j)$. In the contralateral dentate, DCX mRNA-expressing cells were located exclusively in the subgranular layer (Fig. 2i), and DCX mRNA was localized to the perinuclear cytoplasm of these differentiating granule cells. In contrast, no DCX mRNA-expressing cells were detected in the ipsilateral dentate (Fig. 2j), indicating a loss of DCX gene expression at this time point. No hybridization signal was obtained with the sense control (Fig. 2i, inset).

Finally, to quantify the alterations of DCX gene expression by an alternative approach, we performed an independent quantitative real-time RT-PCR analysis for DCX mRNA at two representative time points after KA injection ( $2 \mathrm{~d}$ and 6 weeks; $n=2$ each). In the ipsilateral hippocampus, DCX mRNA levels were reduced as early as $2 \mathrm{~d}$ after KA injection $(62.7 \pm 2.9 \%$ of contralateral levels) (see Fig. $8 b$ ). A dramatic loss of DCX gene expression was
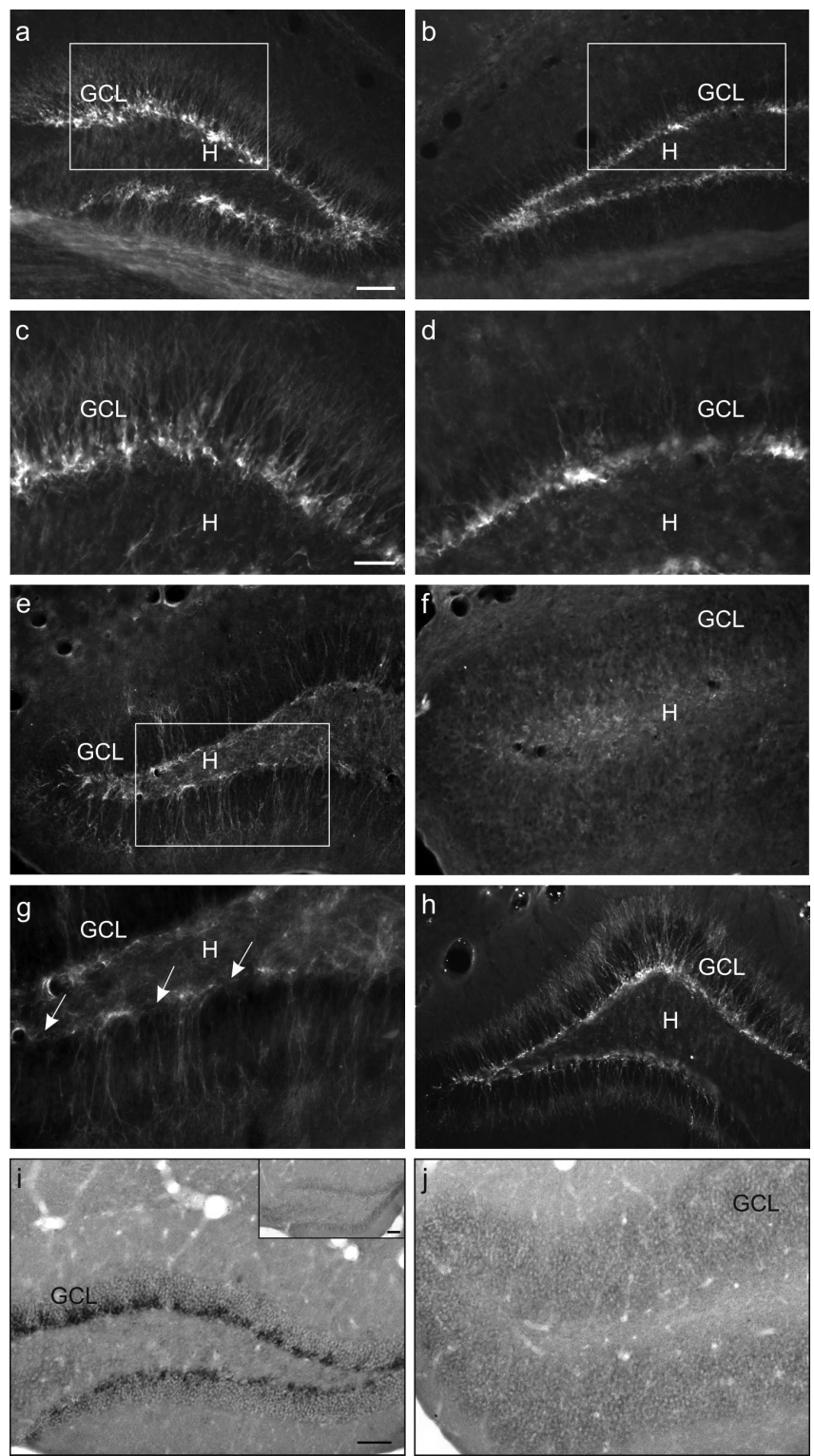

Figure 2. Time course of $D C X$ expression in the dentate gyrus after unilateral intrahippocampal KA injection. Immunocytochemistry and in situ hybridization for $D C X$ were performed on sections of the dentate gyrus at several postlesional intervals as described in Materials and Methods. $\boldsymbol{a}$, Contralateral control side. Many DCX-immunolabeled cells can be observed in the subgranular layer of the dentate gyrus. The apical dendrites of these differentiating neurons extend into the molecular layer. $\boldsymbol{b}$, Ipsilateral dentate gyrus $2 \mathrm{~d}$ after KA injection. The DCX immunolabeling is strongly reduced in apical dendrites and the density of $D C X$-positive neuronal cell bodies is slightly decreased. $\boldsymbol{c}, \boldsymbol{d}$, Representative regions of the subgranular layer (boxed areas in $\boldsymbol{a}$ and $\boldsymbol{b}$, respectively) are magnified to show the reduction in DCX immunostaining in apical dendrites $2 \mathrm{~d}$ after KA injection. $\boldsymbol{e}$, Ipsilateral dentate gyrus $7 \mathrm{~d}$ after KA injection. Many gaps can be detected between DCX-immunolabeled neurons, which appear to be strongly reduced in number. $\boldsymbol{f}$, Ipsilateral dentate gyrus 6 weeks after KA injection. No DCXimmunostained cells can be seen. Note the massive GCD. $\boldsymbol{g}$, High magnification of the boxed area shown in $\boldsymbol{e}$ illustrating the strong reduction in DCX-immunoreactive neurons (arrows). $\boldsymbol{h}$, Ipsilateral dentate gyrus 3 weeks after saline injection. Many DCX-immunolabeled cells located in the subgranular layer of the dentate gyrus extend their apical dendrites into the molecular layer. $\boldsymbol{i}$, Contralateral side. Many DCX mRNA-positive cells are located in the subgranular zone. Inset, sense control. $\boldsymbol{j}$, Ipsilateral side. No DCX mRNA-expressing cells can be observed in the subgranular zone of the dispersed granule cell layer 3 weeks after KA injection. GCL, Granule cell layer; $H$, hilus. Scale bars: $\boldsymbol{a}, \boldsymbol{b}, \boldsymbol{e}, \boldsymbol{f}, \boldsymbol{h}-\boldsymbol{j}$, inset, $75 \mu \mathrm{m} ; \boldsymbol{c}, \boldsymbol{d}, \boldsymbol{g}, 50 \mu \mathrm{m}$.

observed at 6 weeks after KA injection $(21.1 \pm 3.4 \%$ of control $)$. Together, these data, showing that DCX is downregulated, do not support the hypothesis that GCD results from increased neurogenesis after KA injection. 
Early degeneration in the subgranular layer of the KA-injected hippocampus To investigate whether the loss of DCX immunostaining in the subgranular layer of the injected hippocampus was associated with the occurrence of cell death in this region, we performed Fluoro-Jade B staining on hippocampal sections after KA injection. We focused our analysis on four early time points $(1,2,4$, and $7 \mathrm{~d})$, because we had already observed a pronounced decrease in DCX immunostaining at $7 \mathrm{~d}$ after injection (Fig. 2e). In addition, we and others had found that cell death of principal cells, hilar cells, and interneurons occurs during the first days after KA injection (Bouilleret et al., 2000; C. Heinrich and A. Depaulis, unpublished observations).

At $1 \mathrm{~d}(n=2)$ and $2 \mathrm{~d}(n=4)$ after KA injection, Fluoro-Jade B staining of the ipsilateral hippocampus revealed many labeled cells in CA1 (data not shown), CA3, and the hilus (Fig. $3 b, c$ ), whereas no labeling was detected on the contralateral side (Fig. $3 a$ ). In addition, Fluoro-Jade B staining revealed small labeled cells located in the dentate subgranular zone of the injected hippocampus at both time points (Fig. $3 b, c$ ), probably reflecting the degeneration of progenitor cells. A few of these Fluoro-Jade B-positive cells could also represent degenerating, newly born neurons, in agreement with the slight reduction in the density of DCX-positive cell bodies observed on the injected side at this time point (Fig. 3b,d).

At $4 \mathrm{~d}$ after KA injection, a few FluoroJade B-labeled cells were observed in the subgranular zone of the ipsilateral dentate $(n=3)$ (Fig. $3 d)$. In addition, we combined DCX immunocytochemistry and Fluoro-Jade B staining. We found that only a minority of the DCX-immunoreactive cells was Fluoro-Jade B positive, as revealed by image overlay $(n=2)$ (Fig. $3 d-h)$, indicating that the population of postmitotic, differentiating neurons does not undergo extensive degeneration. This is in agreement with the observation that, at $4 \mathrm{~d}$ after KA injection, the row of DCXimmunoreactive neurons appeared mostly intact and similar to that observed at $2 \mathrm{~d}$ (Figs. 2b, 3f). At $7 \mathrm{~d}$ after KA injection, no Fluoro-Jade B staining could be detected in the subgranular zone, neither in the remaining DCX-immunoreactive cells nor in the gaps observed between these neurons $(n=4)$ (Fig. 3i,j). These data provide evidence that the loss of DCX immunostaining observed at this time point does not result from cell death of differentiating neurons but from an impaired replenishment of transiently DCX-expressing cells.

To clarify whether adult granule cells were affected by KA injection, we also examined Fluoro-Jade B-stained hippocampal
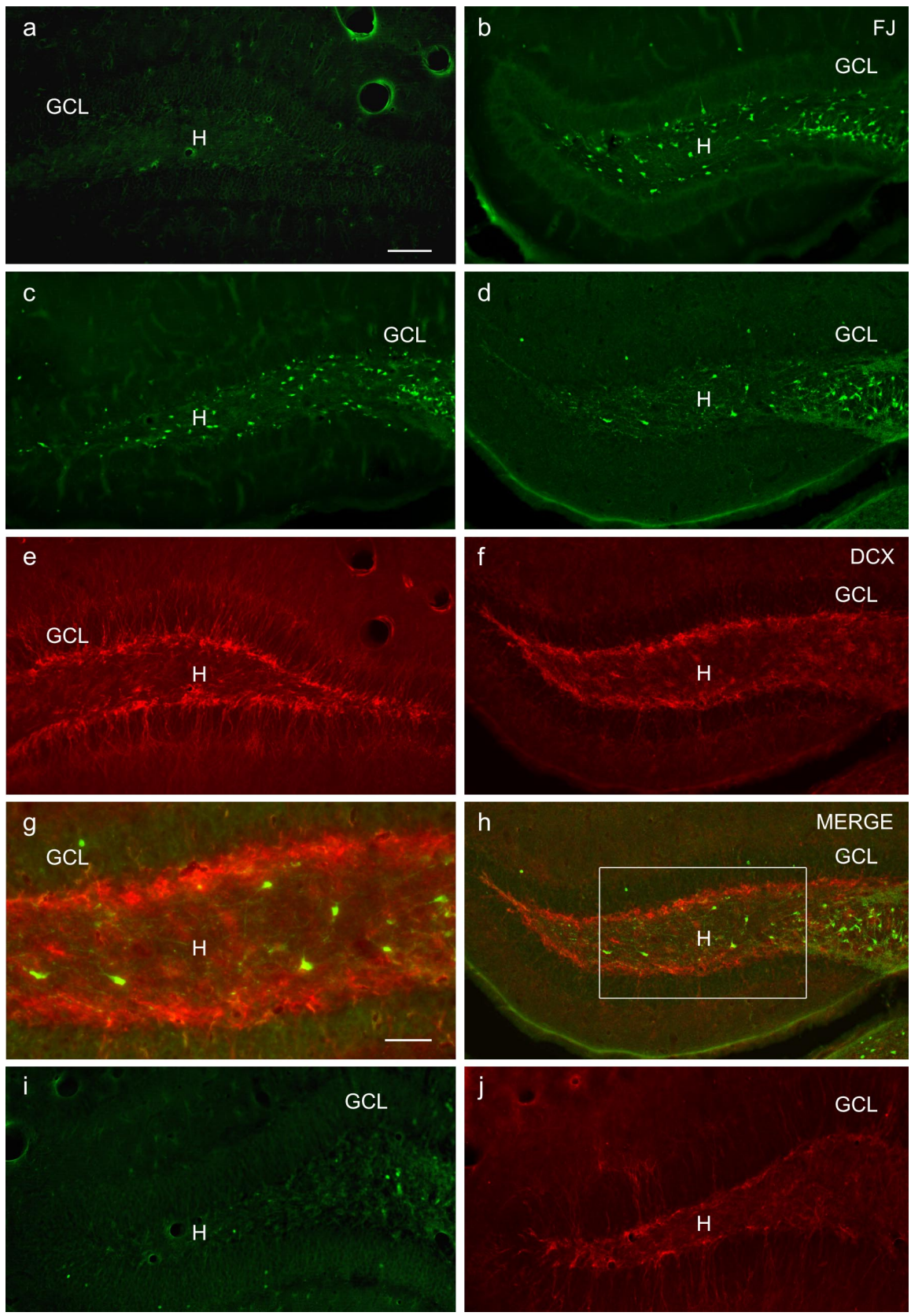

Figure 3. Time course of Fluoro-Jade B staining and double labeling with $D C X$ during the early phase after KA injection. $\boldsymbol{a}-\boldsymbol{d}$ Fluoro-Jade B staining of the contralateral (a) and ipsilateral $(\boldsymbol{b}-\boldsymbol{d})$ dentate gyrus at $1 \mathrm{~d}(\boldsymbol{b}), 2 \mathrm{~d}(\boldsymbol{c})$, and $4 \mathrm{~d}(\boldsymbol{d})$ after KA injection. The contralateral dentate is devoid of any Fluoro-Jade B staining. In the ipsilateral dentate, many Fluoro-Jade B-positive, degenerating neurons are visible in the hilus and in C $A 3$ at all time points. At $1 \mathrm{~d}(\boldsymbol{b})$ and $2 \mathrm{~d}(\boldsymbol{c})$ after injection, Fluoro-Jade B-positive cells were observed in the subgranular layer. Their number decreased by $4 \mathrm{~d}(\boldsymbol{d}) . \boldsymbol{e}, \boldsymbol{f}, D C X$ immunocytochemistry. Although $D C X$ immunostaining is strongly reduced in the apical dendrites, many DCX-positive neurons are still detectable in the subgranular layer of the dentate gyrus $4 \mathrm{~d}$ after KA injection $(\boldsymbol{f})$ compared with the contralateral side $(\boldsymbol{e}) . \boldsymbol{g}, \boldsymbol{h}$, Merged images of $\boldsymbol{d}$ and $\boldsymbol{f}$. $D C X$-positive cells colabeled with Fluoro-Jade $B$ are rarely observed in the subgranular layer of the ipsilateral dentate at $4 \mathrm{~d}$ after KA injection. $\boldsymbol{g}$, High magnification of the boxed area in $\boldsymbol{h} . \boldsymbol{i}, \boldsymbol{j}$, Fluoro-Jade B staining $(\boldsymbol{i})$ and DCX immunolabeling $(\boldsymbol{i})$ of the same hippocampal section $7 \mathrm{~d}$ after injection. At that time point, no Fluoro-Jade B-stained cells can be seen in the subgranular zone. $\mathrm{FJ}$, Fluoro-Jade B; GCL, granule cell layer; H, hilus. Scale bars: $\boldsymbol{a}-\boldsymbol{f}, \boldsymbol{h}-\boldsymbol{j}, 75 \mu \mathrm{m} ; \boldsymbol{g}, 50 \mu \mathrm{m}$.

sections at the level of the granule cell layer at all time points investigated. In addition, we performed TUNEL labeling at 2 and $24 \mathrm{~h}$ after injection. Only very few Fluoro-Jade B-labeled cells were seen in the granule cell layer at all time points investigated (Fig. $3 b-d, i$ ), and we did not observe any TUNEL-positive granule cells (data not shown), indicating that these neurons do not undergo degeneration or apoptosis. 

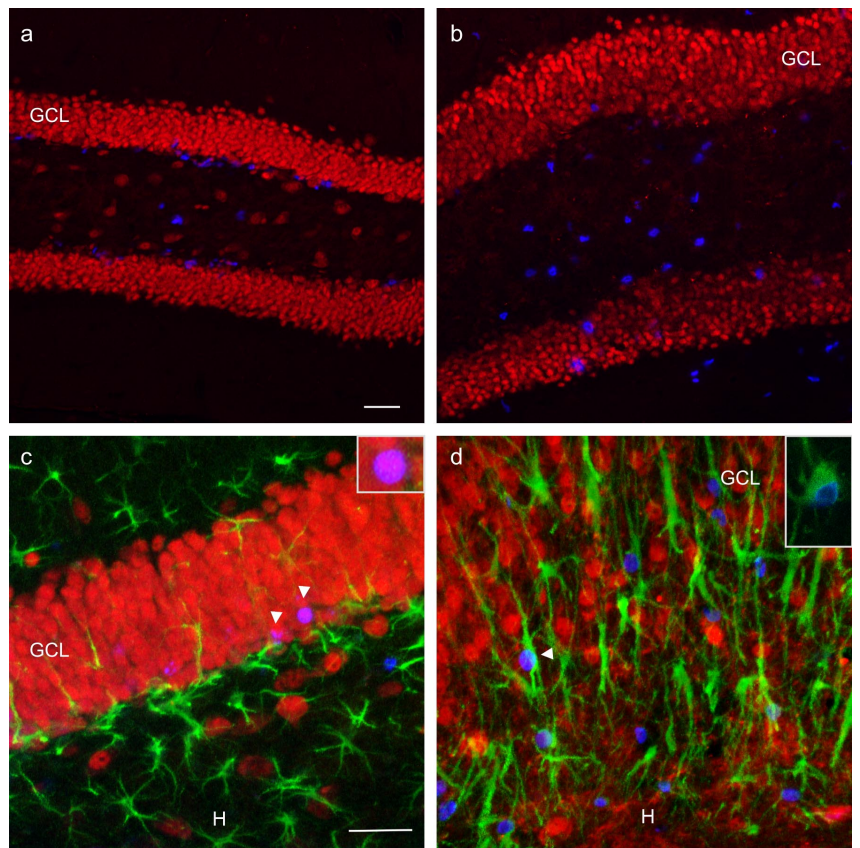

Figure 4. Proliferative response in the dentate gyrus after KA injection. Immunocytochemistry for BrdU, GFAP, and NeuN was performed on vibratome sections at two time points after KA injection: $10 \mathrm{~d}(\boldsymbol{a}, \boldsymbol{b})$ and 5 weeks $(\boldsymbol{c}, \boldsymbol{d})$. Confocal images showing double immunolabeling for BrdU (blue) and NeuN (red) $(\boldsymbol{a}, \boldsymbol{b})$ and triple immunolabeling for BrdU (blue), NeuN (red), and GFAP (green) $(\boldsymbol{c}, \boldsymbol{d}) . \boldsymbol{a}$, Portion of the contralateral dentate showing densely packed NeuNimmunoreactive granule cells and BrdU-labeled cells that are arranged in small clusters in the subgranular layer. $\boldsymbol{b}$, Portion of the ipsilateral dentate showing slightly dispersed NeuN-positive granule cells and an increased number of BrdU-labeled nuclei loosely distributed throughout the hilus and the molecular layer. Note that very few BrdU-positive nuclei can be seen in the subgranular zone. c, Portion of the contralateral suprapyramidal blade showing NeuN/BrdU double-labeled cells (purple; arrowheads and inset) in the subgranular layer as revealed by image overlay. No BrdU/GFAP colabeling was detected. $\boldsymbol{d}$, Portion of the ipsilateral suprapyramidal blade showing dispersed NeuN-positive granule cells that were not double-labeled with BrdU. Note the colocalization of BrdU-labeled nuclei with GFAP (arrowhead and inset). GCL, Granule cell layer; $H$, hilus. Scale bars: $\boldsymbol{a}, \boldsymbol{b}, 50 \mu \mathrm{m} ; \boldsymbol{c}, \boldsymbol{d}, 20 \mu \mathrm{m}$.

We conclude that KA injection probably affects progenitor cells in the subgranular zone but does not cause differentiating and mature granule cells to degenerate. Because of the loss of precursor cells, the continuous addition of transiently DCXexpressing, differentiating granule cells is affected, thus accounting for the gradual loss of DCX immunostaining in the subgranular layer.

\section{Early but transient increase in cell proliferation in the KA-injected hippocampus}

Because the loss of DCX immunostaining pointed to a reduced neurogenesis in the injected hippocampus, we assessed the proliferation rate directly by combining KA injection and BrdU labeling. Two different BrdU injection protocols were used (see schematic diagram in supplemental Fig. 1, available at www. jneurosci.org as supplemental material). In the first group, mice received BrdU injections four times per day at 6 and $7 \mathrm{~d}$ after KA injection (group $1 ; n=6)$ and were killed either $10 \mathrm{~d}(n=3)$ or 5 weeks $(n=3)$ after KA injection. In the second group, mice were given BrdU twice daily over 7 consecutive days, starting $8 \mathrm{~d}$ after KA administration, and were killed after the last BrdU injection corresponding to a $14 \mathrm{~d}$ survival time (group $2 ; n=3$ ). Subsequently, BrdU incorporation was detected by immunocytochemistry.

BrdU-labeled nuclei were observed in the subgranular layer of the contralateral dentate gyrus in group 1 (Fig. $4 a$ ) and group 2 (data not shown). These labeled cells were arranged in small, isolated clusters as described previously (Seki and Arai, 1993; Kuhn et al., 1996; Parent et al., 1997; Lee et al., 2003). In the ipsilateral dentate gyrus, the number of newly generated cells, incorporating BrdU on days 6 and 7 after KA injection, was increased compared with the contralateral side (group 1) (Fig. 4b). However, their distribution was different: BrdU-labeled cells were loosely distributed throughout the hilus and the molecular layer of the dentate gyrus (Fig. 4b). Remarkably, only a few BrdUlabeled nuclei were observed in the subgranular zone compared with the contralateral side (Fig. $4 b$ ), suggesting a cessation of proliferation in this region, very much in agreement with the hypothesized loss of progenitor cells. During the second week after KA injection, the rate of cell proliferation dropped below that on the contralateral side, and very few BrdU-labeled cells were found in the ipsilateral dentate gyrus $14 \mathrm{~d}$ after KA injection (group 2; data not shown), thus indicating a cessation of proliferation.

To determine the phenotype of the BrdU-labeled cells generated during the first week after KA injection, we performed a confocal analysis of hippocampal sections, triple-immunolabeled for BrdU, NeuN, and GFAP (markers for mature neurons and astrocytes, respectively) at 5 weeks after KA treatment (group $1 ; n=$ 3 ). On the contralateral side, BrdU-positive cells in the subgranular layer were double-labeled with NeuN (purple) showing a neuronal phenotype (Fig. $4 c$, arrowheads and inset). Only a few BrdU/GFAP-double-labeled cells were found. Conversely, in the ipsilateral dentate, the majority of BrdU-positive nuclei colocalized with GFAP (Fig. $4 d$, arrowhead and inset) paralleled by a general increase in GFAP immunolabeling. None of the NeuNpositive and dispersed granule cells was double-labeled with BrdU, clearly indicating that GCD does not result from a malpositioning of newly generated neurons.

These data show that KA injection stimulates an early increase in astroglial cell proliferation on the injected side, which is followed by a virtually complete cessation of proliferative activity. Together, these results do not support the hypothesis that GCD is associated with an increased rate of neurogenesis.

\section{KA-induced microgliosis in the injected hippocampus}

As shown in Figure $4 b$, many BrdU-positive, newly generated cells were loosely distributed throughout the hilus, probably representing proliferating microglial cells. To test this hypothesis, hippocampal sections of mice killed at $7 \mathrm{~d}$ after KA treatment $(n=2)$ were immunolabeled for Iba-1, a marker for both resting and activated microglia.

In the contralateral hippocampus, Iba-1 immunolabeling revealed a small number of weakly stained microglial cells (Fig. 5a). At higher magnification, the majority of these cells exhibited a ramified shape with thin processes, characteristic of the resting state (Fig. 5c) (Kreutzberg, 1996). In the KA-injected hippocampus, however, we detected a strong increase in the number and staining intensity of microglial cells, which were mainly concentrated in the areas of neuronal degeneration (in Ammon's horn and hilus), but not in the dentate granule cell layer (Fig. 5b). In addition, higher magnification revealed that these cells displayed enlarged somata with short, thick processes, characteristic of activated microglia (Fig. 5d) (Kreutzberg, 1996). When compared with Figure $5 b$, the distribution of Iba-1-positive cells in the ipsilateral hilus (Fig. $5 d$ ) was very similar to the pattern observed for BrdU-labeled cells, suggesting proliferation of microglial cells in this region within the first week after KA injection (see also Lee et al., 2003). 

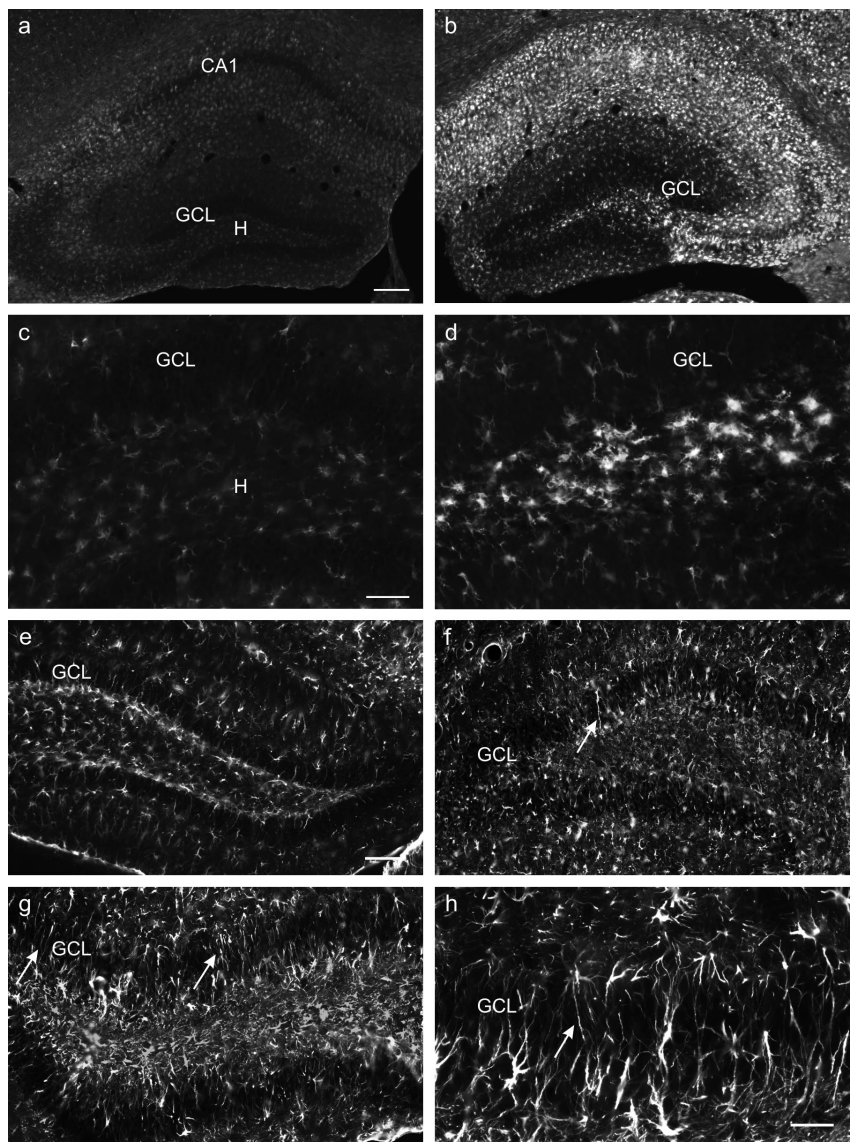

Figure 5. Response of microglial cells and astrocytes to KA injection as revealed by immunostaining for lba-1 and GFAP. $\boldsymbol{a}$, Weak immunostaining of resting microglial cells in the contralateral hippocampus. $\boldsymbol{b}$, Dramatic increase in the number and staining intensity of lba-1positive microglial cells in the hippocampus $7 \mathrm{~d}$ after KA injection. Note that labeled microglial cells are mainly concentrated in areas of neuronal degeneration (Ammon's horn, hilus, and subgranular zone) but not in the granule cell layer. $\boldsymbol{c}, \boldsymbol{d}$, High magnification of the contralateral and ipsilateral hilus shown in $\boldsymbol{a}$ and $\boldsymbol{b}$. Note the enlarged somata and short processes of activated Iba-1-positive cells on the injected side ( $\boldsymbol{d}$ ) and their absence on the contralateral side (c). $\boldsymbol{e}, \boldsymbol{f}$, Broadening of the granule cell layer is accompanied by the appearance of long GFAPpositive fibers (arrow) in the granule cell layer $7 \mathrm{~d}$ after KA injection (f) compared with the contralateral side (e). $\boldsymbol{g}, \boldsymbol{h}$, Increase in GFAP-positive fiber density (arrows) in the ipsilateral dentate gyrus $14 \mathrm{~d}$ after KA accompanied by progressive GCD. $\boldsymbol{h}$, High magnification of a portion of the suprapyramidal granule cell layer shown in $(g)$, illustrating the dense GFAP-positive scaffold in the region of dispersion. GCL, Granule cell layer; H, hilus. Scale bars: $\boldsymbol{a}, \boldsymbol{b}, 100 \mu \mathrm{m}$; $\boldsymbol{c}$, $\boldsymbol{d}, \boldsymbol{h}, 50 \mu \mathrm{m} ; \boldsymbol{e}-\boldsymbol{g}, 75 \mu \mathrm{m}$

\section{Changes in GFAP- and vimentin-positive glial cells in the KA-injected hippocampus}

As shown in Figure 1, a progressive increase in granule cell width occurs within 3 weeks after KA injection. Because our data suggested that GCD was not caused by increased neurogenesis and malpositioning of newly born neurons, we hypothesized that adult granule cells, initially organized in a densely packed layer, could re-initiate migration or were pushed apart by hypertrophic astrocytic processes. To address this issue, hippocampal sections of KA-injected animals were first immunolabeled for GFAP, which specifically labels astrocytes and radial glial cells in the dentate gyrus (Weiss et al., 2003). As soon as GCD became apparent ( $7 \mathrm{~d}$ after KA injection; $n=2$ ), long GFAP-positive glial fibers resembling radial fibers were observed within the enlarged granule cell layer (Fig. $5 f$ ) that were neither detectable on the contralateral side (Fig. 5e) nor after saline injection $(n=2$; data not shown). The density of GFAP-positive fibers increased in parallel with the development of GCD at 2 weeks $(n=2)$ (Fig. $5 g, h), 3$ weeks $(n=6)$ (Fig. $6 d)$, and 6 weeks $(n=5$; data not shown) after KA injection, forming a massive glial scaffold in the region of GCD.

To further investigate the precise location of this network within the dispersed granule cell layer, we performed a confocal analysis of hippocampal sections double-immunolabeled for NeuN and GFAP, 3 weeks after KA injection $(n=2)$ (Fig. 6). In the contralateral noninjected hippocampus, NeuN-positive round granule cells formed a tightly packed layer with only a few GFAP-positive astrocytic processes (Fig. $6 a, c$ ). On the ipsilateral side, however, the elongated, NeuN-positive granule cells were distributed in a column-like manner (Fig. 6b). In the same area, a dense radially orientated GFAP-positive fiber scaffold was visible (Fig. $6 d$ ) that interdigitated between the dispersed granule cells, as revealed by image overlay (Fig. $6 f$ ). At higher magnification, NeuN-labeled granule cells were seen in close association with these glial processes (Fig. $6 e, g, h$, arrow).

Finally, we performed immunostaining for vimentin, RC2, and GLAST, markers for radial glial cells (Hockfield and McKay, 1985; Campbell and Götz, 2002). The pattern of vimentin immunostaining observed 3 weeks after KA injection $(n=2)$ was very similar to that of GFAP: in the contralateral dentate gyrus, only a few star-shaped cells were present in the subgranular zone (Fig. $6 i$ ), whereas on the ipsilateral side, a dense vimentin-positive fiber scaffold was noted (Fig. 6j). However, neither RC2 nor GLAST antibodies labeled these cells (data not shown), as noticed previously for dentate radial glial cells during development (Förster et al., 2002). Together, these results show that there is a massive hypertrophy of GFAP- and vimentin-positive glial cells with an extension of long radially orientated processes in the region of dispersion.

\section{Decrease in reelin mRNA expression in the KA-injected hippocampus}

In the dentate gyrus of MTLE patients, the extent of GCD correlates with a local reelin deficiency (Haas et al., 2002). To investigate whether (1) similar molecular changes are found in the present mouse model of MTLE and (2) reelin expression is altered in parallel with the development of GCD, we performed a time-course analysis of reelin mRNA expression after KA injection. Reelin mRNA was localized by in situ hybridization on hippocampal sections of saline- and KA-injected mice at several postoperative time points $(2 \mathrm{~d}, 7 \mathrm{~d}, 14 \mathrm{~d}, 6$ weeks, and 4 months after injection). For quantitative evaluation, reelin mRNApositive cells were counted along the hippocampal fissure as described in Materials and Methods.

In the contralateral hippocampus of KA-injected mice and in both hippocampi of saline-injected controls, many reelin mRNA-expressing neurons were found in the CA1 and CA3 region, in the hilus, and along the hippocampal fissure (Fig. 7a,b). As early as $2 \mathrm{~d}$ after KA injection, there was a dramatic decrease in reelin mRNA-expressing cells all over the injected hippocampus: notably, no labeled cells were found in CA1, CA3, and the hilus $(n=5)$ (Fig. $7 c)$. This loss of reelin mRNA expression was observed at all time points investigated (Fig. $7 c-f$ ). Moreover, the reelin mRNA-synthesizing neurons that were still observed along the hippocampal fissure on the injected side remained significantly reduced in number compared with the contralateral side, in parallel with a progressive development of GCD (66.4 and $70.0 \%$ of the contralateral side, $p<0.05$ and $p<0.0001$, at $2(n=$ 4 ) and $6(n=6)$ weeks after KA injection, respectively) (Figs. 7e, $f$, $8 a)$. At 4 months after KA injection $(n=2)$, only a few reelin 

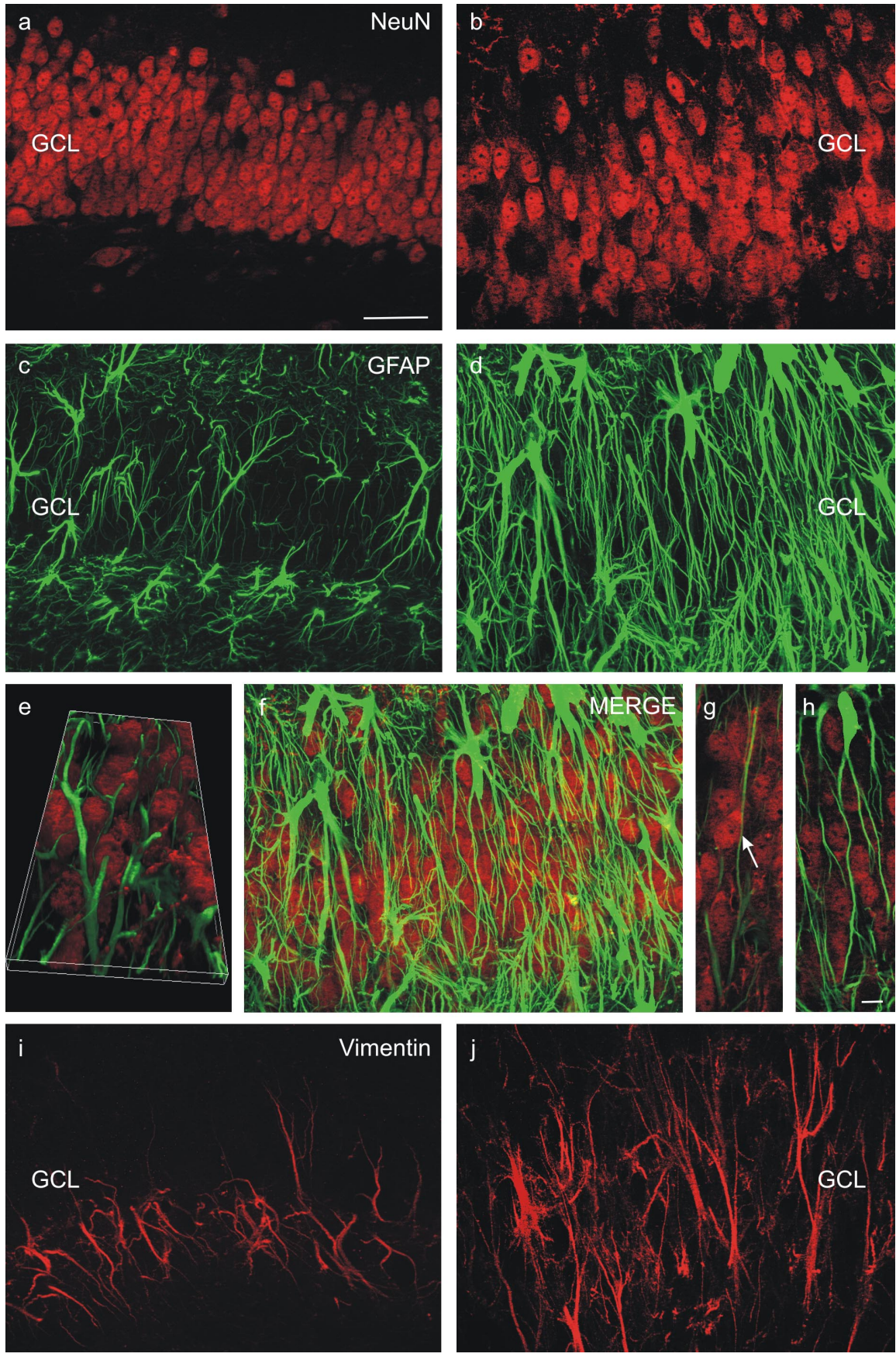

Figure 6. Presence of a glial scaffold in the region of GCD after KA injection. Immunocytochemistry for NeuN, GFAP, and vimentin was performed on vibratome sections 3 weeks after KA injection. $\boldsymbol{a}-\boldsymbol{h}$, Double immunolabeling for NeuN (red) and GFAP (green). $\boldsymbol{a}$, Portion of the contralateral suprapyramidal blade of the granule cell layer showing round and densely packed NeuNimmunoreactive granule cells. $\boldsymbol{b}$, Portion of the ipsilateral suprapyramidal blade with dispersed NeuN-positive granule cells. Note the increase in granule cell layer width and differences in granule cell morphology: dispersed granule cells display an elongated shape and are distributed in a column-like manner. c, GFAP staining of the section shown in $\boldsymbol{a}$. Only a few GFAP-labeled processes are seen in the granule cell layer. $\boldsymbol{d}$, GFAP staining of the section shown in $\boldsymbol{b}$ reveals a dense glial scaffold of radially aligned fibers extending from the hilus toward the molecular layer. $\boldsymbol{e}-\boldsymbol{h}$, Merged images. $\boldsymbol{f}, 0$ verlay of $\boldsymbol{b}$ and $\boldsymbol{d}$. The GFAP-labeled glial network extends through the entire dispersed region of NeuN-positive granule cells. $\boldsymbol{e}, \boldsymbol{g}, \boldsymbol{h}$, High magnification reveals individual long radial glial-like processes in close association with dispersed granule cells $(\boldsymbol{g}$, arrow). $\boldsymbol{i}, \boldsymbol{j}$, Vimentin immunostaining. $\boldsymbol{i}$, Portion of the contralateral suprapyramidal blade. Star-like, vimentin-positive cells can be observed in the subgranular zone. $\boldsymbol{j}$, Portion of the ipsilateral suprapyramidal blade. Note the radially orientated, vimentin-positive processes in the region of dispersion, similar to the GFAP-positive fibers in $\boldsymbol{d} . \boldsymbol{a}, \boldsymbol{b}, \boldsymbol{g}, \boldsymbol{h}$, Single confocal images. $\boldsymbol{c}, \boldsymbol{d}, \boldsymbol{f}, \boldsymbol{i}, \boldsymbol{j}$, Flattened confocal stacks. $\boldsymbol{e}$, Three-dimensional reconstruction of a confocal stack. $\mathrm{GCL}$, Granule cell layer. Scale bars: $\boldsymbol{a}-\boldsymbol{d}, \boldsymbol{f}, \boldsymbol{i}, \boldsymbol{j}, 20 \mu \mathrm{m} ; \boldsymbol{e}, \boldsymbol{g}, \boldsymbol{h}, 5 \mu \mathrm{m}$.
mRNA-expressing cells were detected in the entire KA-injected hippocampus, at a time when GCD reached an enormous extent (data not shown).

In contrast, no changes in reelin mRNA expression were observed in the contralateral hippocampus or after saline injection, independent of the postinjection survival time ( $2 \mathrm{~d}, n=1 ; 6$ weeks, $n=3$ ) (Fig. $7 a, b)$. The mean number of reelin mRNApositive neurons was almost identical on the ipsilateral and contralateral side (68.4 \pm 3.6 and $65.9 \pm 0.2$, respectively) at 6 weeks after saline injection. In situ hybridization with the sense control was always negative (data not shown).

To further substantiate this loss of reelin gene expression, we performed realtime RT-PCR for reelin mRNA at two representative time points (i.e., $2 \mathrm{~d}$ and 6 weeks after KA injection; $n=2$ each). In the injected hippocampus, reelin mRNA levels dropped to $15.9 \pm 3.0 \%$ of the contralateral side as early as $2 \mathrm{~d}$ after KA injection (Fig. 8b). Similarly, at 6 weeks after injection, reelin mRNA levels were strongly reduced in the injected hippocampus compared with the contralateral side $(31.3 \pm 4.2 \%$ of contralateral levels) (Fig. 8b). These data showing a strong decrease in reelin mRNA expression at the level of the entire injected hippocampus confirm the counts of reelin mRNAexpressing cells that were performed along the hippocampal fissure (Fig. 8a).

Finally, to exclude that the significant drop of reelin expression was the result of an unspecific effect of KA, we also investigated the expression of synapsin I, which codes for a neuron-specific protein, and BDNF mRNA by in situ hybridization in the same animals at $2 \mathrm{~d}$ after KA injection $(n=2)$ (supplemental Fig. 2, available at www.jneurosci.org as supplemental material). We found a differential response of both mRNA species in the injected hippocampus: synapsin I mRNA was equally expressed by granule cells on both sides (supplemental Fig. 2a,b, available at www.jneurosci.org as supplemental material), whereas BDNF mRNA was strongly upregulated in dentate granule cells on the injected side (supplemental Fig. $2 e, f$, available at www.jneurosci.org as supplemental material). To confirm the specificity of the downregulation of reelin expression, we also performed real-time RT-PCR for BDNF mRNA at $2 \mathrm{~d}$ and 6 weeks after KA injection $(n=2$ each). Contrary to reelin, BDNF mRNA levels were increased at $2 \mathrm{~d}$ and strongly upregulated at 6 weeks on the ipsilateral side after KA injection (152.0 \pm 31.7 and $646.5 \pm 171.7 \%$ of the contralat- 

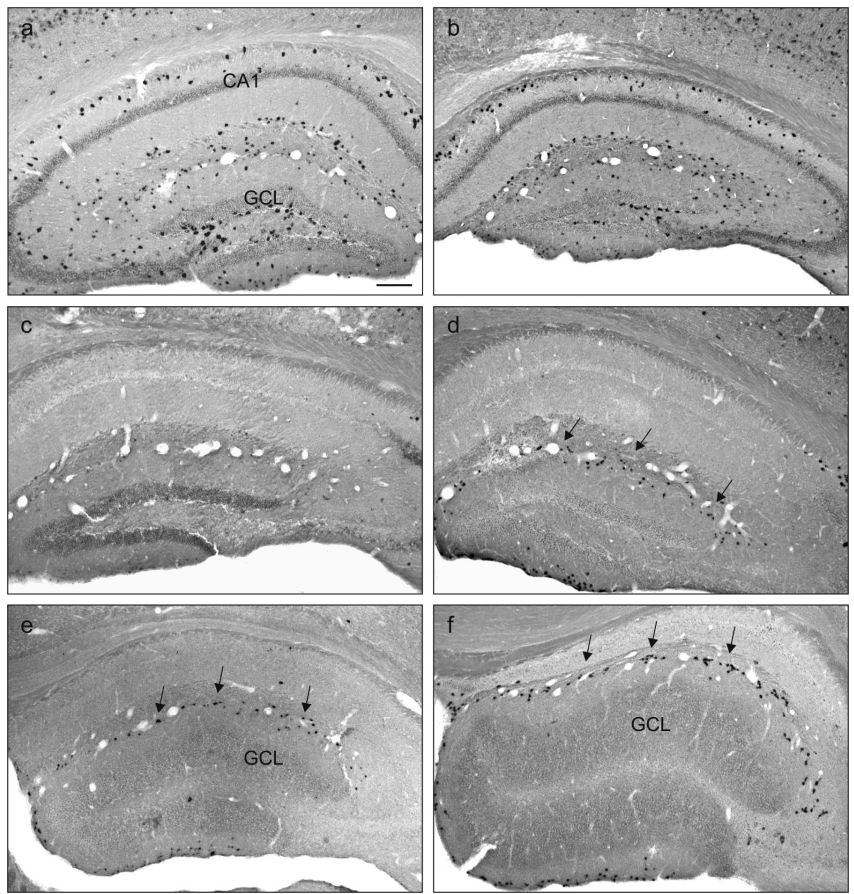

Figure 7. Time course of reelin mRNA expression in the mouse hippocampus after unilateral intrahippocampal KA injection. Reelin mRNA-expressing neurons were localized by in situ hybridization as described in Materials and Methods. $\boldsymbol{a}$, Contralateral hippocampus. Many reelin mRNA-positive neurons are present in CA1 and CA3, in the hilus, and along the hippocampal fissure. $\boldsymbol{b}$, Ipsilateral hippocampus of a saline-injected control mouse $2 \mathrm{~d}$ after injection. The distribution of reelin $m R N A$-positive neurons is similar to that in $\boldsymbol{a} . \boldsymbol{c}-\boldsymbol{f}$, Ipsilateral hippocampus $2 \mathrm{~d}(\boldsymbol{c}), 7 \mathrm{~d}(\boldsymbol{d}), 2$ weeks $(\boldsymbol{e})$, and 6 weeks $(\boldsymbol{f})$ after KA injection. $\boldsymbol{c}$, A dramatic reduction in reelin mRNA expression is evident all over the hippocampus $2 \mathrm{~d}$ after KA injection $(n=5)$. Except for a few labeled cells, which are still present along the hippocampal fissure, no reelin mRNApositive neurons can be detected in CA1 and in the hilus. $\boldsymbol{D}$, Seven days after KA injection ( $n=$ 5), a few reelin mRNA-positive neurons can be observed along the hippocampal fissure (arrows). $\boldsymbol{e}, \boldsymbol{f}$, Numbers of reelin mRNA-expressing cells remain low along the hippocampal fissure after $2(\boldsymbol{e} ; n=4)$ and $6(\boldsymbol{f} ; n=6)$ weeks after KA injection, in parallel with a progressive development of GCD. GCL, Granule cell layer. Scale bar, $100 \mu \mathrm{m}$.

eral levels, respectively) (Fig. 8c), in agreement with previous studies (Suzuki et al., 1995). These results demonstrate that the loss of reelin mRNA expression (Fig. $7 c-f$; supplemental Fig. $2 c, d$, available at www.jneurosci.org as supplemental material) does not result from an unspecific effect on gene expression in general, because other mRNAs were either not affected (synapsin I) or strongly upregulated (BDNF).

Together, these results provide additional evidence that a local and significant loss of reelin mRNA synthesis occurs in the injected hippocampus and may be causally related to the development of GCD.

\section{Chronic infusion of the reelin-neutralizing CR-50 antibody into the hippocampus of adult mice}

To investigate whether reelin is causally involved in the maintenance of lamination in the adult hippocampus and whether GCD is the result of a local reelin deficiency, we chronically applied the reelin-neutralizing CR-50 antibody to the hippocampus of adult mice. CR-50 is a well characterized monoclonal antibody that has been shown to be effective in neutralizing reelin function in vivo and in vitro (Ogawa et al., 1995; Nakajima et al., 1997). Osmotic pumps (secretion period, $7 \mathrm{~d}$ ) containing CR-50 antibody solution or normal mouse IgG were connected to stereotaxically implanted steel cannulas positioned in the right hippocampus. After a

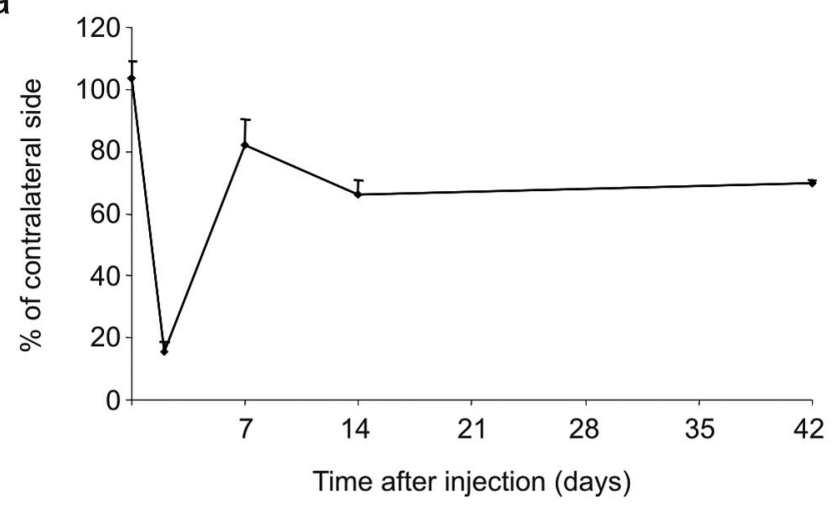

b

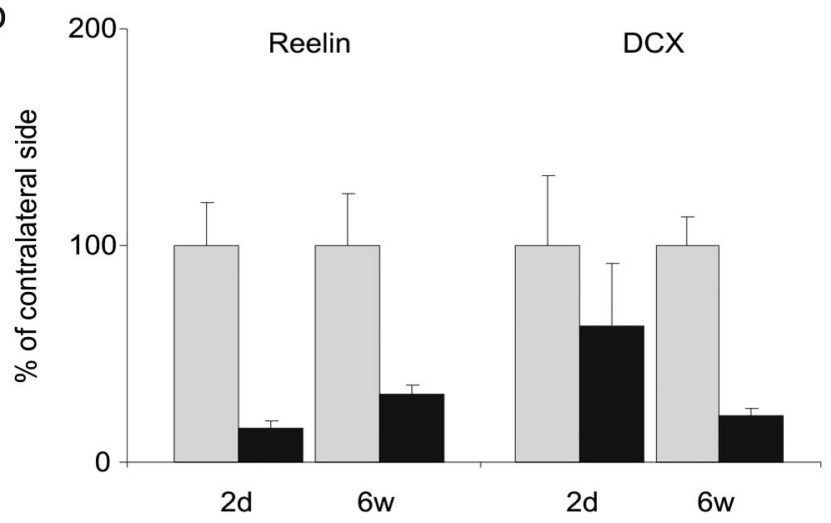

C

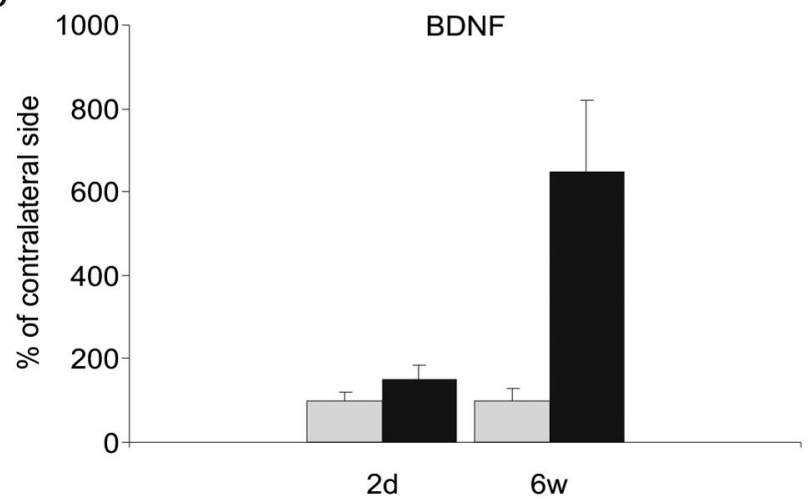

Figure 8. Quantitative evaluation of changes in gene expression in the hippocampus after KA injection. $\boldsymbol{a}$, Semiquantitative evaluation of reelin mRNA expression at five time points $(0 \mathrm{~d}$, $2 \mathrm{~d}, 7 \mathrm{~d}, 14 \mathrm{~d}$, and 6 weeks) after KA injection. Reelin mRNA-positive neurons were counted along the hippocampal fissure on the injected and contralateral side in at least five sections per animal ( $n=4$ per time point). Mean values ( \pm SEM) are expressed as percentage of the contralateral side. The numbers of reelin mRNA-synthesizing cells were significantly reduced in the injected hippocampus at $2 \mathrm{~d}, 2$ weeks, and 6 weeks after KA injection $(p<0.01, p<0.05$, and $p<0.0001$ compared with the contralateral side; two-way, repeated-measure ANOVA, followed by a post hoc paired-samples $t$ test). Conversely, no differences in the number of reelin-positive cells were observed between both hippocampi in naive control mice (day $0 ; p>$ 0.1; two-way, repeated-measure ANOVA, followed by a post hoc paired samples $t$ test). $\boldsymbol{b}, \boldsymbol{c}$, Histograms showing the expression levels of reelin, DCX, and BDNF mRNAs in the contralateral (gray bars) and ipsilateral (black bars) hippocampus at two representative time points [i.e., $2 \mathrm{~d}$ (2d) and 6 weeks ( $6 \mathrm{w}$ ) after KA injection]. mRNA levels were determined by quantitative realtime RT-PCR in extracts from microdissected hippocampi. Measurements were performed in duplicate, and relative mRNA levels were normalized with S12 RNA as an internal standard. Mean values ( \pm SEM) are expressed as percentage of the contralateral side. 

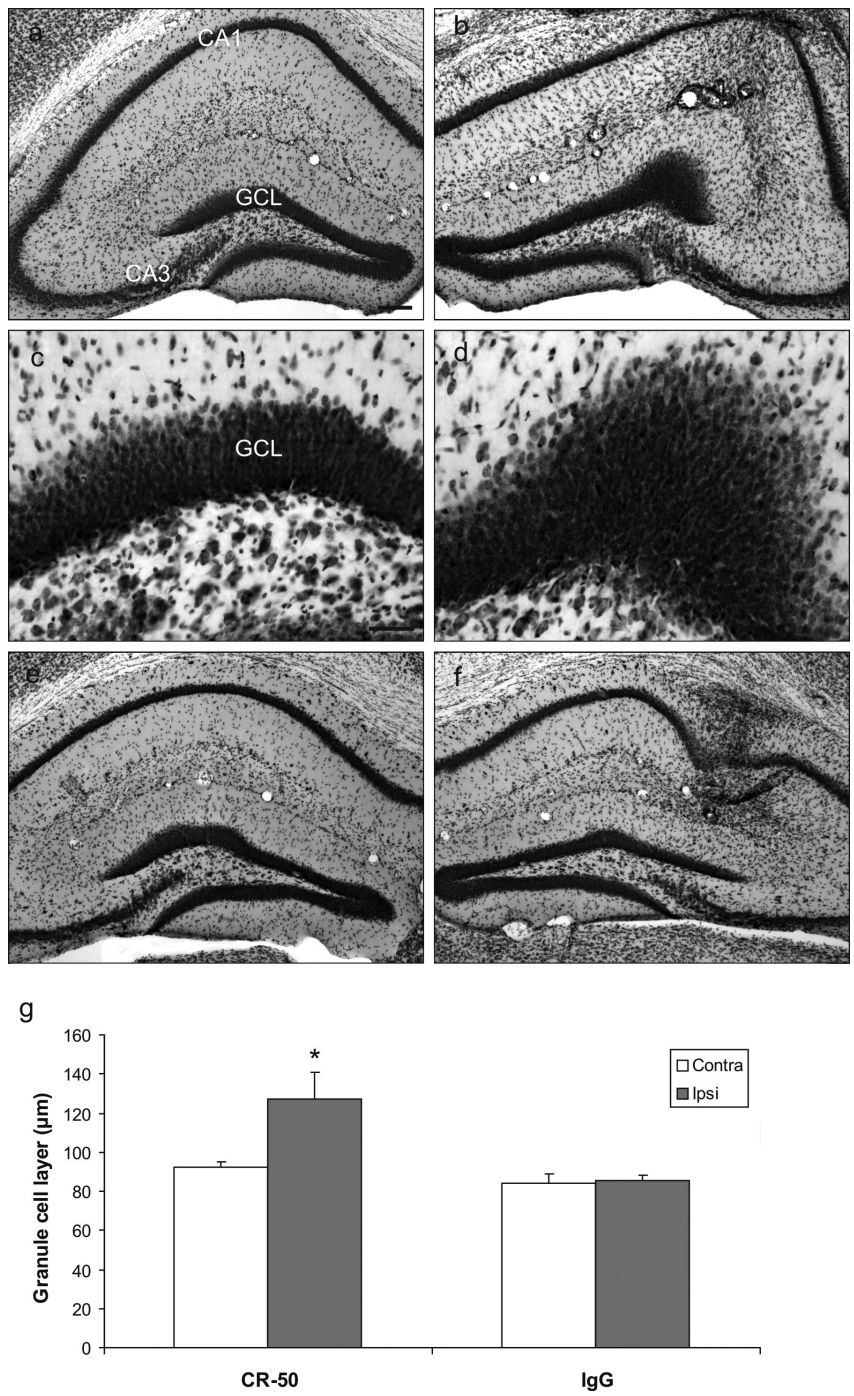

Figure 9. Effect of chronic CR-50 antibody infusion into the dentate gyrus of adult mice. Antibodies were chronically administered by osmotic pumps inserted in the right hippocampus over a period of $7 \mathrm{~d}$, followed by another $7 \mathrm{~d}$ of survival. $\boldsymbol{a}-\boldsymbol{d}$, Morphological changes were visualized by cresyl violet staining. Infusion of $C R-50$ resulted in a massive increase in the width of the granule cell layer $(\boldsymbol{b}, \boldsymbol{d})$ compared with the contralateral side $(\boldsymbol{a}, \boldsymbol{c})$. The widening of the granule cell layer was confined to the site of injection, indicating that a local neutralization of reelin altered the lamination of adult granule cells. $\boldsymbol{e}, \boldsymbol{f}$, No change in lamination was observed after infusion of mouse control lgG. $\boldsymbol{e}$, Contralateral side. $\boldsymbol{f}$, Ipsilateral side. Scale bars: $\boldsymbol{a}, \boldsymbol{b}, \boldsymbol{e}, \boldsymbol{f}$, $150 \mu \mathrm{m} ; \boldsymbol{c}, \boldsymbol{d}, 40 \mu \mathrm{m} . \boldsymbol{g}$, Quantitative evaluation of GCL width in CR-50-infused $(n=6)$ and $\lg$-infused $(n=5)$ hippocampi. The width of the GCL was measured in the ipsilateral and contralateral hippocampus in five sections per animal, and five measurements were taken per hippocampus. Mean values \pm SEM are shown. In the CR-50-injected animals, the width of the $\mathrm{GCL}$ was significantly increased compared with the contralateral side $(p<0.0277)$ using the two-sample Wilcoxon rank-sum test. Comparisons were of the unpaired two-sided type.

a survival time of $14 \mathrm{~d}$, the animals were killed and the morphology of the dentate gyrus was analyzed by cresyl violet staining. In all six animals that chronically received CR-50, the width of the granule cell layer was enlarged compared with the contralateral side or with the IgG-infused control group (Fig. 9). This effect was locally restricted to the region beneath the injection site indicating that CR-50 diffusion was limited (Fig. 9b,d). Notably, a similar effect was not observed below the injection site of mouse IgG (Fig. 9e,f). The diffusion of the CR-50 antibody was visualized by immunostaining with an anti-mouse Cy3 antibody. Labeling was predominantly seen in the region above the suprapy- ramidal blade of the dentate (data not shown). Quantitative evaluation of the granule cell layer enlargement after CR-50 infusion revealed a significant ipsilateral increase in granule cell layer width $(126.89 \mu \mathrm{m} \pm 14.29)$ compared with the contralateral side (91.99 $\mu \mathrm{m} \pm 2.90)$ or with the IgG control (ipsilateral, $85.16 \pm 2.86 \mu \mathrm{m}$; contralateral, $84.30 \pm 4.33 \mu \mathrm{m}$ ), showing the specificity of the effect (Fig. $9 g$ ). These data clearly show that after reelin inactivation, adult granule cells lose their compact layering similar to the situation after KA injection in which GCD development is accompanied by a loss of reelin gene expression.

\section{Discussion}

Our results show that GCD after KA injection does not result from increased neurogenesis and abnormal migration of newly generated granule cells. On the contrary, intrahippocampal KA injection was found to cause a cessation of neurogenesis on the injected side (where GCD progressively developed) but did not interfere with neurogenesis on the contralateral side (where no GCD was observed). Hence, GCD is a process that affects mature, differentiated granule cells. In addition, we show a loss of reelin mRNA synthesis on the side of KA injection (where GCD occurs) but not on the contralateral side (where a compact granule cell layer is preserved). In addition, neutralization of reelin in naive animals produced a widening of the granule cell layer. Together, our findings suggest that GCD in MTLE results from an aberrant migration or a displacement of mature, not newly generated, granule cells, likely caused by a decrease in reelin synthesis.

\section{GCD does not result from a malpositioning of newly generated granule cells}

We have hypothesized previously that GCD may develop from a malpositioning of newly born neurons (Haas et al., 2002). This was an appealing hypothesis, because neurogenesis occurs in the dentate gyrus throughout life and can be stimulated by prolonged epileptic seizures in rodents (Parent et al., 1997; Scharfman et al., 2000). However, the results of the present study do not support this hypothesis. Rather, we provide here several lines of evidence of a KA-mediated decrease in granule cell neurogenesis in the epileptic hippocampus of adult mice. First, we show a gradual loss of DCX mRNA and protein expression in the dentate gyrus on the KA-injected side. This progressive disappearance of DCX expression in the subgranular layer is likely to result from the maturation of granule cells in the absence of a substantial number of neuronal precursor cells that could replenish the pool of transiently DCX-expressing, immature granule cells (Brown et al., 2003). Second, BrdU labeling revealed a cessation of proliferation in the subgranular zone on the injected side during the first week after KA administration despite an increased mitotic activity in the hilus. Our labelings suggest that the majority of these newly generated cells did not acquire a neuronal phenotype but differentiated into microglia and GFAP-positive cells, as observed similarly by others (Hüttmann et al., 2003; Lee et al., 2003; Kralic et al., 2005). Moreover, during the second week after KA administration, there was a virtually complete cessation of mitotic activity on the injected side (i.e., during a period when GCD continued to develop). In contrast, on the contralateral side, where we observed a normal, ongoing neurogenesis, no GCD developed. Thus, our results show that GCD after KA injection (and probably also GCD in the human epileptic hippocampus) does not result from increased neurogenesis and aberrant migration of newly generated neurons but from a translocation of mature, differentiated granule cells. In line with our observations, a reduction in dentate neurogenesis has been reported in MTLE pa- 
tients (Mathern et al., 2002), under chronic epileptic conditions in rats (Hattiangady et al., 2004), and after intrahippocampal kainate injection in mice (Kralic et al., 2005). Moreover, the stimulation of dentate neurogenesis observed after systemic pilocarpine and KA injections occurs only transiently and is not associated with the development of GCD (Parent et al., 1997; Gray and Sundstrom, 1998; Scharfman et al., 2000; Jessberger et al., 2005).

\section{Reelin keeps granule cells in register}

We found recently that a local reelin deficiency in the marginal zone of the dentate gyrus correlated with the extent of GCD in tissue samples from epileptic patients (Haas et al., 2002; Frotscher et al., 2003). During development, reelin controls granule cell lamination by acting as a positional signal for migrating neurons (Zhao et al., 2004). We hypothesized that GCD in MTLE patients results from the observed changes in reelin expression. This is supported by the well known loss of granule cell lamination in mouse mutants lacking reelin, its lipoprotein receptors, or Dab1. In all of these mutants, the granule cells are scattered over the hilus and molecular layer (Rakic and Caviness, 1995; Sheldon et al., 1997; Trommsdorff et al., 1999; Drakew et al., 2002). In human tissue samples, we could not clarify whether GCD resulted from a developmental defect, an aberrant migration of newly generated granule cells associated with a reelin deficiency, or a translocation of mature granule cells. The present study provides evidence that GCD is a process that affects differentiated granule cells. GCD developed on the side of KA injection where a cessation of neurogenesis was observed. GCD was absent on the contralateral side where neurogenesis continued. On the injected side, GCD was accompanied by a significant loss of reelin expression, whereas no such loss was noticed on the contralateral side, where a compact granule cell layer was preserved. Moreover, we found that this loss of reelin mRNA expression rapidly occurred after the initial status epilepticus, as early as $2 \mathrm{~d}$ after KA injection, thus preceding the onset of GCD. We also show that a significant reduction in reelin mRNA synthesis was persisting in parallel with the progressive development of GCD.

Additional evidence that reelin is crucial for the maintenance of granule cell lamination in the adult dentate gyrus comes from our CR-50 infusion experiments. In vivo neutralization of reelin by chronic infusion of the reelin-blocking CR-50 antibody leads to a significant widening of the granule cell layer. In contrast, infusion of mouse IgG did not have this effect. CR-50 has been shown to effectively neutralize reelin function in a variety of experimental approaches during development (Ogawa et al., 1995; Nakajima et al., 1997). However, this is the first report that demonstrates that chronic CR-50 application to the adult hippocampus neutralizes reelin function and, in consequence, results in a widening of the granule cell layer very similar to GCD.

In view of the present results, we suggest that reelin is not only important for the formation but also for the maintenance of granule cell lamination in the adult hippocampus, as hypothesized previously (Haas et al., 2002; Frotscher et al., 2003). Under normal conditions, as in the contralateral dentate gyrus, reelin in the marginal zone may keep the granule cells in register (i.e., does not allow them to invade the molecular layer). In contrast, in the injected hippocampus, a decreased reelin expression in the marginal zone may result in a loss of dense granule cell packing. Therefore, we suggest that reelin is not only a positional signal for migrating granule cells during development (Zhao et al., 2004) but also controls a compact lamination of mature granule cells throughout life. We think that the loss of reelin mRNAexpressing cells in the injected hippocampus is attributable to the well known susceptibility of reelin-synthesizing Cajal-Retzius cells to excess glutamate and glutamate agonists, respectively (Del Rio et al., 1997). We cannot rule out, however, that other factors are involved in the downregulation of reelin synthesis. We and others (Guilhem et al., 1996) have shown a long-lasting upregulation of BDNF expression in the dentate gyrus after KA injection. $\mathrm{BDNF}$, in turn, is known to negatively regulate reelin synthesis during cortical development (Ringstedt et al., 1998), and it is important for GCD formation (Giulhem et al., 1996).

How does GCD take place? Is this an active, aberrant migration of mature granule cells along glial fibers or a displacement of granule cells resulting from glial proliferation and hypertrophy in the dentate? We cannot answer this question unless we have visualized the process. Our present data are compatible with both hypotheses. We observed proliferation and process extension of GFAP- and vimentin-positive glial cells on the injected side in parallel with GCD formation. The hypertrophic glial cells may have sneaked in between the granule cells resulting in a less compact granule cell layer. Alternatively, there may be a proliferation and/or rejuvenation of radial glial cells with an extension of radial glial fibers providing a scaffold for a potential migration of adult granule cells. A significant increase in glial fiber length was, in fact, found, and we observed NeuN-positive granule cells attached to these GFAP-labeled fibers. Whatever process will be found to underlie the dispersion of granule cells in MTLE, we have shown here that a reelin deficiency is involved and that mature granule cells are the players.

In conclusion, the reelin signaling pathway is important for the maintenance of mature granule cells in a compact layer. In view of the present results, the following scenario may also hold true for human MTLE: seizure-associated excessive glutamate release induces dentate progenitor cell degeneration, alters reelin expression in the hippocampus, and eventually results in a dispersion of mature granule cells.

\section{References}

Altman J, Das GD (1965) Autoradiographic and histological evidence of postnatal hippocampal neurogenesis in rats. J Comp Neurol 124:319-335.

Bouilleret V, Ridoux V, Depaulis A, Marescaux C, Nehlig A, Le Gal La Salle G (1999) Recurrent seizures and hippocampal sclerosis following intrahippocampal kainate injection in adult mice: electroencephalography, histopathology and synaptic reorganization similar to mesial temporal lobe epilepsy. Neuroscience 89:717-729.

Bouilleret V, Loup F, Kiener T, Marescaux C, Fritschy JM (2000) Early loss of interneurons and delayed subunit-specific changes in GABA(A)receptor expression in a mouse model of mesial temporal lobe epilepsy. Hippocampus 10:305-324.

Brown JP, Couillard-Despres S, Cooper-Kuhn CM, Winkler J, Aigner L, Kuhn HG (2003) Transient expression of doublecortin during adult neurogenesis. J Comp Neurol 467:1-10.

Burbach GJ, Hellweg R, Haas CA, del Turco D, Deicke U, Abramowski D, Jucker M, Staufenbiel M, Deller T (2004) Induction of brain-derived neurotrophic factor in plaque-associated glial cells of aged APP23 transgenic mice. J Neurosci 24:2421-2430.

Campbell K, Götz M (2002) Radial glia: multi-purpose cells for vertebrate brain development. Trends Neurosci 25:235-238.

Cendes F, Kahane P, Brodie M, Andermann F (2002) The mesio-temporal lobe epilepsy syndrome. In: Epileptic syndromes in infancy, childhood and adolescence (Roger J, Bureau M, Dravet C, Genton P, Tassinari CA, Wolf P, eds), pp 513-530. Eastleigh, UK: John Libbey and Company.

Couillard-Despres S, Winner B, Schaubeck S, Aigner R, Vroemen M, Weidner N, Bogdahn U, Winkler J, Kuhn HG, Aigner L (2005) Doublecortin expression levels in adult brain reflect neurogenesis. Eur J Neurosci 21:1-14.

D’Arcangelo G, Miao GG, Chen SC, Soares HD, Morgan JI, Curran T (1995) A protein related to extracellular matrix proteins deleted in the mouse mutant reeler. Nature 374:719-723. 
D’Arcangelo G, Homayouni R, Keshvara L, Rice DS, Sheldon M, Curran T (1999) Reelin is a ligand for lipoprotein receptors. Neuron 24:471-479.

Del Rio JA, Heimrich B, Borrell V, Förster E, Drakew A, Alcantara S, Nakajima K, Miyata T, Ogawa M, Mikoshiba K, Derer P, Frotscher M, Soriano E (1997) A role for Cajal-Retzius cells and reelin in the development of hippocampal connections. Nature 385:70-74.

des Portes V, Pinard JM, Billuart P, Vinet MC, Koulakoff A, Carrie A, Gelot A, Dupuis E, Motte J, Berwald-Netter Y, Catala M, Kahn A, Beldjord C, Chelly J (1998) A novel CNS gene required for neuronal migration and involved in X-linked subcortical laminar heterotopia and lissencephaly syndrome. Cell 92:51-61.

Drakew A, Deller T, Heimrich B, Gebhardt C, Del Turco D, Tielsch A, Förster E, Herz J, Frotscher M (2002) Dentate granule cells in reeler mutants and VLDLR and ApoER2 knockout mice. Exp Neurol 176:12-24.

Eksioglu YZ, Scheffer IE, Cardenas P, Knoll J, DiMario F, Ramsby G, Berg M, Kamuro K, Berkovic SF, Duyk GM, Parisis J, Huttenlocher PR, Walsh CA (1996) Periventricular heterotopia: an X-linked dominant locus causing aberrant cerebral cortical development. Neuron 16:77-87.

Eriksson PS, Perfilieva E, Bjork-Eriksson T, Alborn AM, Nordborg C, Peterson DA, Gage FH (1998) Neurogenesis in the adult human hippocampus. Nat Med 4:1313-1317.

Förster E, Tielsch A, Saum B, Weiss K-H, Johanssen C, Graus-Porta D, Müller U, Frotscher M (2002) Reelin, disabled 1 and $\beta_{1}$ integrins are required for the formation of the radial glial scaffold in the hippocampus. Proc Natl Acad Sci USA 99:13178-13183.

Frotscher M (1998) Cajal-Retzius cells, reelin and the formation of layers. Curr Opin Neurobiol 8:570-575.

Frotscher M, Haas CA, Förster E (2003) Reelin controls granule cell migration in the dentate gyrus by acting on the radial scaffold. Cereb Cortex 13:634-640.

Gray WP, Sundstrom LE (1998) Kainic acid increases the proliferation of granule cell progenitors in the dentate gyrus of the adult rat. Brain Res 790:52-59.

Guilhem D, Dreyfus PA, Makiura Y, Suzuki F, Onteniente B (1996) Short increase of BDNF messenger RNA triggers kainic acid-induced neuronal hypertrophy in adult mice. Neuroscience 72:923-931.

Haas CA, Deller T, Naumann T, Frotscher M (1996) Selective expression of the immediate early gene $c$-Jun in axotomized rat medial septal neurons is not related to neuronal degeneration. J Neurosci 16:1884-1903.

Haas CA, Deller T, Krsnik Z, Tielsch A, Woods A, Frotscher M (2000) Entorhinal cortex lesion does not alter reelin mRNA expression in the dentate gyrus of young and adult rats. Neuroscience 97:25-31.

Haas CA, Dudeck O, Kirsch M, Huszka C, Kann G, Pollak S, Zentner J, Frotscher M (2002) Role for reelin in the development of granule cell dispersion in temporal lobe epilepsy. J Neurosci 22:5797-5802.

Hattiangady B, Rao MS, Shetty AK (2004) Chronic temporal lobe epilepsy is associated with severely declined neurogenesis in the adult hippocampus. Neurobiol Dis 17:473-490.

Hirotsune S, Takahare T, Sasaki N, Hirosè K, Yoshiki A, Ohashi T, Kusakabe M, Murakami Y, Muramatsu M, Watanabe S, Nakao K, Katsuki M, Hayashizaki Y (1995) The reeler gene encodes a protein with an EGF-like motif expressed by pioneer neurons. Nat Genet 10:77-83.

Hockfield S, McKay RD (1985) Identification of major cell classes in the developing mammalian nervous system. J Neurosci 5:3310-3328.

Hong SE, Shugart YY, Hung DT, Al Shahwan S, Garnt PE, Hourihane JO’B, Martin NDT, Walsh C (2000) Autosomal recessive lissencephaly with cerebellar hypoplasia is associated with human RELN mutations. Nat Genet 26:93-96.

Houser CR (1990) Granule cell dispersion in the dentate gyrus of humans with temporal lobe epilepsy. Brain Res 535:195-204.

Howell BW, Hawkes R, Soriano P, Cooper JA (1997) Neuronal positioning in the developing brain is regulated by mouse disabled-1. Nature 389:733-737.

Hüttmann K, Sadgrove M, Wallraff A, Hinterkeuser S, Kirchhoff F, Steinhäuser C, Gray W (2003) Seizures preferentially stimulate proliferation of radial glia-like astrocytes in the adult dentate gyrus: functional and immunocytochemical analysis. Eur J Neurosci 18:2769-2778.

Jessberger S, Römer B, Babu H, Kempermann G (2005) Seizures induce proliferation and dispersion of doublecortin-positive hippocampal progenitor cells. Exp Neurol 196:342-351.

Kaplan MS, Hinds JW (1977) Neurogenesis in the adult rat: electron microscopic analysis of light radioautographs. Science 197:1092-1094.

Kralic JE, Ledergerber DA, Frischy J-M (2005) Disruption of the neurogenic potential of the dentate gyrus in a mouse model of temporal epilepsy with focal seizures. Eur J Neurosci 22:1916-1927.

Kreutzberg GW (1996) Microglia: a sensor for pathological events in the CNS. Trends Neurosci 19:312-318.

Kuhn HG, Dickinson-Anson H, Gage FH (1996) Neurogenesis in the dentate gyrus of the adult rat: age-related decrease of neuronal progenitor proliferation. J Neurosci 16:2027-2033.

Lee J, Auyeung WW, Mattson MP (2003) Interactive effects of excitotoxic injury and dietary restriction on microgliosis and neurogenesis in the hippocampus of adult mice. Neuromol Med 4:179-196.

Lurton D, El Bahh B, Sundstrom L, Rougier A (1998) Granule cell dispersion is correlated with early epileptic events in human temporal epilepsy. J Neurol Sci 154:133-136.

Margerison JH, Corsellis JAN (1966) Epilepsy and the temporal lobe. Brain 89:499-530.

Mathern GW, Leiphart JL, De Vera A, Adelson PD, Seki T, Neder L, Leite JP (2002) Seizures decrease postnatal neurogenesis and granule cell development in the human fascia dentata. Epilepsia 43 [Suppl 5]:68-73.

Nakajima K, Mikoshiba K, Miyata T, Yamamoto H, Kudo C, Ogawa M (1997) Disruption of hippocampal development in vivo by CR-50 mAb against reelin. Proc Natl Acad Sci USA 94:8196-8201.

Ogawa M, Miyata T, Nakanjima K, Yagyu K, Seike M, Ikenaka K, Yamamoto H, Mikoshiba K (1995) The reeler gene-associated antigen on CajalRetzius neurons is a crucial molecule for laminar organization of cortical neurons. Neuron 14:899-912.

Palmini A, Andermann F, Olivier A, Tampieri D, Robitaille Y, Andermann E, Wright G (1991) Focal neuronal migration disorders and intractable partial epilepsy: a study of 30 patients. Ann Neurol 30:741-749.

Parent JM, Yu TW. Leibowitz RT, Geschwind DH, Sloviter RS, Lowenstein DH (1997) Dentate granule cell neurogenesis is increased by seizures and contributes to aberrant network reorganization in the adult rat hippocampus. J Neurosci 17:3727-3738.

Rakic P, Caviness VS Jr (1995) Cortical development: view from neurological mutants two decades later. Neuron 14:1101-1104.

Rao MS, Shetty AK (2004) Efficacy of doublecortin as a marker to analyse the absolute number and dendritic growth of newly generated neurons in the adult dentate gyrus. Eur J Neurosci 19:234-246.

Riban V, Bouilleret V, Pham-Le BT, Fritschy J-M, Marescaux C, Depaulis A (2002) Evolution of hippocampal epileptic activity during the development of hippocampal sclerosis in a mouse model of temporal lobe epilepsy. Neuroscience 112:101-111.

Ringstedt T, Linnarsson S, Wagner J, Lendahl U, Kokaia Z, Arenas E, Ernfors P, Ibanez CF (1998) BDNF regulates reelin expression and Cajal-Retzius cell development in the cerebral cortex. Neuron 21:305-315.

Scharfman HE, Goodman JH, Sollas AL (2000) Granule-like neurons at the hilar/CA3 pyramidal cell border after status epilepticus and their synchrony with area CA3 pyramdial cells: functional implications of seizureinduced neurogenesis. J Neurosci 20:6144-6158.

Schmued LC, Hopkins KJ (2000) Fluoro-Jade: novel fluorochromes for detecting toxicant-induced neuronal degeneration. Toxicol Pathol 28:91-99.

Seki T, Arai Y (1993) Highly polysialylated neural cell adhesion molecule (NCAM-H) is expressed by newly generated granule cells in the dentate gyrus of the adult rat. J Neurosci 13:2351-2358.

Sheldon M, Rice DS, d'Arcangelo G, Yoneshima H, Nakajima M, Mikoshiba K, Howell BW, Cooper JA, Goldowitz D, Curran T (1997) Scrambler and yotari disrupt the disabled gene and produce a reeler-like phenotype in mice. Nature 389:730-733.

Suzuki F, Junier MP, Guilhem D, Sorensen JC, Onteniente B (1995) Morphogenetic effect of kainate on adult hippocampal neurons associated with a prolonged expression of brain-derived neurotrophic factor. Neuroscience 64:665-674.

Tissir F, Goffinet A (2003) Reelin and brain development. Nat Rev Neurosci 4:496-505.

Trommsdorff M, Gotthardt T, Hiesberger T, Shelton J, Stockinger W, Nimpf J, Hammer RE, Richardson JA, Herz J (1999) Reeler/disabled-like disruption of neuronal migration in knockout mice lacking the VLDL receptor and ApoE receptor 2. Cell 97:689-701.

Weiss KH, Johanssen C, Tielsch A, Herz J, Deller T, Frotscher M, Förster E (2003) Malformation of the radial scaffold in the dentate gyrus of reeler mice, scrambler mice and ApoER2/VLDLR-deficient mice. J Comp Neurol 460:56-65.

Zhao S, Chai X, Förster E, Frotscher M (2004) Reelin is a positional signal for the lamination of dentate granule cells. Development 131:5117-5125. 